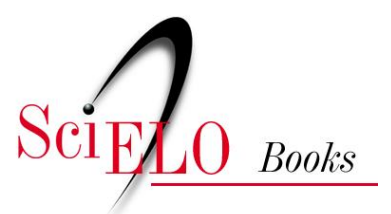

\title{
Expedição Moreira César
}

\author{
Euclides da Cunha
}

\section{SciELO Books / SciELO Livros / SciELO Libros}

CUNHA, E. Expedição Moreira César. In: Os sertões [online]. Rio de Janeiro: Centro Edelstein de Pesquisas Sociais, 2010. pp. 240-295. ISBN: 978-85-7982-007-6.

https://doi.org/10.7476/9788579820076.0006.

\section{() poumain}

This work is free of known copyright restrictions. http://creativecommons.org/publicdomain/mark/1.0/

Este trabalho está livre de restrições de direito de autor e/ou de direitos conexos conhecidas.

http://creativecommons.org/publicdomain/mark/1.0/

Esta obra está libre de restricciones conocidas de derechos autorales. http://creativecommons.org/publicdomain/mark/1.0/ 


\section{EXPEDIÇÃO MOREIRA CÉSAR}

I. O coronel Antônio Moreira César e o meio que o celebrizou. Primeira expedição regular. Como a aguardam os jagunços.

II. Partida de Monte Santo. Primeiros erros. Nova estrada. Psicologia do soldado.

III. O primeiro encontro. Pitombas. “Em acelerado!” Dois cartões de visita a Antônio Conselheiro. No alto da Favela. Um olhar sobre Canudos.

IV. A ordem de batalha e o terreno. Cidadela-mundéu. Ataques. Saques antes do triunfo. Recuo. Ao bater da AveMaria.

V. Sobre o Alto do Mário.

VI. Retirada; debandada; fuga. Um arsenal ao ar livre e uma diversão cruel.

\section{Capítulo I}

\section{o coronel Moreira César e o meio que o celebrizou}

O novo insucesso das armas legais, imprevisto para toda a gente, coincidia com uma fase crítica da nossa história.

A pique ainda das lamentáveis consequências de sanguinolenta guerra civil, que rematara ininterrupta série de sedições e revoltas, emergentes desde os primeiros dias do novo regime, a sociedade brasileira, em 1897, tinha alto grau de receptividade para a intrusão de todos os elementos revolucionários e dispersivos. E quando mais tarde alguém se abalançar a definir, à luz de expressivos documentos, a sua psicologia interessante naquela quadra, demonstrará a inadaptabilidade do povo à legislação superior do sistema político recém-inaugurado, como se este, pelo avantajar-se em demasia ao curso de uma evolução vagarosa, tivesse, como efeito predominante, alastrar sobre o país, que se amolentara no marasmo monárquico, intenso espírito de desordem, precipitando a República por um declive onde os desastres repontavam, ritmicamente, delatando a marcha cíclica de uma moléstia.

O governo civil, iniciado em 1894, não tivera a base essencial de uma opinião pública organizada. Encontrara o país dividido em vitoriosos e vencidos. E quedara na impotência de corrigir uma situação que não sendo francamente revolucionária e não sendo também normal, repelia por igual os recursos extremos da força e o influxo sereno das leis. Estava defronte de uma sociedade que, progredindo em saltos, da máxima frouxidão ao rigorismo máximo, das conspirações incessantes aos estados de sítio repetidos, parecia espelhar incisivo contraste entre a sua organização intelectual imperfeita e a organização política incompreendida.

De sorte que, lhe sendo impossível substituir o lento trabalho de evolução para alevantar a primeira ao nível da última, deixava que se verificasse o fenômeno inverso: a significação superior dos princípios democráticos decaía — sofismada, invertida, anulada. 


\section{Floriano Peixoto}

Não havia obstar essa descensão. O governo anterior, do marechal Floriano Peixoto, tivera, pelas circunstâncias especialíssimas que o rodearam, função combatente e demolidora. Mas, no abater a indisciplina emergente de sucessivas sedições, agravara a instabilidade social e fora de algum modo contraproducente, violando flagrantemente um programa preestabelecido. Assim é que nascendo do revide triunfante contra um golpe de Estado violador das garantias constitucionais, criara o processo da suspensão de garantias; abraçado tenazmente à Constituição, afogava-a; fazendo da Legalidade a maior síntese de seus desígnios, aquela palavra, distendida à consagração de todos os crimes, transmudara-se na fórmula antinômica de uma terra sem leis. De sorte que o inflexível marechal de ferro tivera, talvez involuntariamente, porque a sua figura original é ainda um intricado enigma, desfeita a missão a que se devotara. Apelando, nas aperturas das crises que o assoberbaram, incondicionalmente, para todos os recursos, para todos os meios e para todos os adeptos, surgissem de onde surgissem, agia inteiramente fora da amplitude da opinião nacional, entre as paixões e interesses de um partido que, salvante bem raras exceções, congregava todos os medíocres ambiciosos que, por instinto natural de defesa, evitam as imposições severas de um meio social mais culto. E ao debelar, nos últimos dias de seu governo, a Revolta de Setembro, que enfeixara todas as rebeldias contrariadas e todos os tumultos dos anos anteriores, formara, latentes, prestes a explodir, os germes de mais perigosos levantes.

Destruíra e criara revoltosos. Abatera a desordem com a desordem. Ao deixar o poder não levara todos os que o haviam acompanhado nos transes dificílimos do governo. Ficaram muitos agitadores, robustecidos numa intensa aprendizagem de tropelias, e estes viam-se contrafeitos no plano secundário a que naturalmente volviam. Traziam o movimento irreprimível de uma carreira fácil e vertiginosa demais para estacar de súbito: dilataram-na pela nova situação adentro.

Viu-se, então, um caso vulgaríssimo de psicologia coletiva: colhida de surpresa, a maioria do país inerte e absolutamente neutral constituiu-se veículo propício à transmissão de todos os elementos condenáveis que cada cidadão, isoladamente, deplorava. Segundo o processo instintivo, que lembra na esfera social a herança de remotíssima predisposição biológica, tão bem expressa no mimismo psichico de que nos fala Scipio Sighele, as maiorias conscientes, mas tímidas, revestiam-se, em parte, da mesma feição moral dos medíocres atrevidos que lhes tomavam a frente. Surgiram, então, na tribuna, na imprensa e nas ruas - sobretudo nas ruas individualidades que nas situações normais tombariam à pressão do próprio ridículo. Sem ideais, sem orientação nobilitadora, peados num estreito círculo de ideias, em que o entusiasmo suspeito pela República se aliava a nativismo extemporâneo e à cópia grosseira de um jacobinismo pouco lisonjeiro à história — aqueles agitadores começaram a viver da exploração pecaminosa de um cadáver. O túmulo do marechal Floriano Peixoto foi transmudado na arca de aliança da rebeldia impenitente e o nome do grande homem fez-se a palavra de ordem da desordem.

A retração criminosa da maioria pensante do país permitia todos os excessos; e no meio da indiferença geral todas as mediocridades irritadiças conseguiram imprimir àquela quadra, felizmente transitória e breve, o traço mais vivo que a caracteriza. Não lhes bastavam as cisões remanescentes, nem os assustava uma situação econômica desesperadora: anelavam avolumar aquelas e tornar a última insolúvel. E como o exército se erigia, ilogicamente, desde o movimento abolicionista até à proclamação da República, em elemento ponderador das agitações nacionais, cortejavamno, captavam-no, atraíam-no afanosa e imprudentemente.

Ora, de todo o exército, um coronel de infantaria, Antônio Moreira César, era quem parecia haver herdado a tenacidade rara do grande debelador de revoltas.

O feiticismo político exigia manipansos de farda.

Escolheram-no para novo ídolo.

\section{Moreira César}

E à nova do desastre, avolumando a gravidade da luta nos sertões, o governo não descobriu quem melhor lhe pudesse balancear as exigências gravíssimas. Escolheu-o para chefe da expedição vingadora.

Em torno do nomeado criara-se uma legenda de bravura. 
Recém-vindo de Santa Catarina, onde fora o principal ator no epílogo da campanha federalista do Rio Grande, tinha excepcional renome feito de aclamações e apodos, consoante o modo de julgar incoerente e extremado da época em que eram vivos os mínimos incidentes da guerra civil distendida da baía do Rio de Janeiro para o Sul, pela revolta da esquadra.

Entre dois extremos, do arrojo de Gumercindo Saraiva à abnegação de Gomes Carneiro, a opinião nacional oscilava espelhando os mais díspares conceitos no aquilatar vitoriosos e vencidos; e nessa instabilidade, nesse baralhamento, nesse afogueado expandir da nossa sentimentalidade suspeita, o que de fato se fazia em todos os tons, com. todas as cores e sob aspectos vários - era a caricatura do heroísmo. Os heróis imortais de quarto de hora, destinados a suprema consagração de uma placa à esquina das ruas, entravam, surpreendidos e de repente, pela história dentro, aos encontrões, como intrusos desapontados, sem que se pudesse saber se eram bandidos ou santos, envoltos de panegíricos e convícios, surgindo entre ditirambos ferventes, ironias e invectivas despiedadas, da sangueira de Inhanduí, da chacina de Campo Osório, do cerco memorável da Lapa, dos barrocais do Pico do Diabo, ou do platonismo marcial de Itararé. todos.

Irrompiam a granel. Eram legião. Todos saudados; amaldiçoados

Ora, entre eles, o coronel Moreira César era figura à parte.

Surpreendiam-se igualmente ao vê-lo admiradores e adversários. O aspecto reduzia-lhe a fama. De figura diminuta - um tórax desfibrado sobre pernas arcadas em parêntese - era organicamente inapto para a carreira que abraçara.

Faltava-lhe esse aprumo e competição inteiriça que no soldado são a base física da coragem.

Apertado na farda, que raro deixava, o dólmã feito para ombros de adolescente frágil agravava-lhe a postura.

A fisionomia inexpressiva e mórbida completava-lhe o porte desgracioso e exíguo. Nada, absolutamente, traía a energia surpreendedora e temibilidade rara de que dera provas, naquele rosto de convalescente sem uma linha original e firme: - pálido, alongado pela calva em que se expandia a fronte bombeada, e mal alumiado por olhar mortiço, velado de tristeza permanente.

Era uma face imóvel como um molde de cera, tendo a impenetrabilidade oriunda da própria atonia muscular. Os grandes paroxismos da cólera e a alacridade mais forte, ali deviam amortecer-se inapercebidos, na lassidão dos tecidos, deixando-a sempre fixamente impassível e rígida.

Aos que pela primeira vez o viam custava-lhes admitir que estivesse naquele homem de gesto lento e frio, maneiras corteses e algo tímidas, o campeador brilhante, ou o demônio crudelíssimo que idealizavam. Não tinha os traços característicos nem de um, nem de outro. Isto, talvez, porque fosse as duas coisas ao mesmo tempo.

Justificam-se os que o aplaudiam e os que o invectivavam. Naquela individualidade singular entrechocavam-se, antinômicas, tendências monstruosas e qualidades superiores, umas e outras no máximo grau de intensidade. Era tenaz, paciente, dedicado, leal, impávido, cruel, vingativo, ambicioso. Uma alma proteiforme constrangida em organização fragílima.

Aqueles atributos, porém, velava-os reserva cautelosa e sistemática. Um único homem os percebeu ou decifrou bem, o marechal Floriano Peixoto. Tinha para isto a afinidade de inclinações idênticas. Aproveitou-o, na ocasião oportuna, como Luís XII aproveitaria Bayard, se pudesse enxertar na bravura romanesca do cavaleiro sem máculas as astúcias de Fra Diávolo.

Moreira César estava longe da altitude do primeiro e mais longe ainda da depressão moral do último. Não seria, entretanto, imperdoável exagero considerá-lo misto reduzido de ambos. Alguma coisa de grande e incompleto, como se a evolução prodigiosa do predestinado parasse, antes da seleção final dos requisitos raros com que o aparelhara, precisamente na fase crítica em que ele fosse definir-se como herói ou como facínora. Assim, era um desequilibrado. Em sua alma a extrema dedicação esvaía-se no extremo ódio, a calma soberana em desabrimentos repentinos e a bravura cavalheiresca na barbaridade revoltante.

Tinha o temperamento desigual e bizarro de um epilético provado, encobrindo a instabilidade nervosa de doente em placidez enganadora. 
Entretanto, não raro, a sua serenidade partia-se rota pelos movimentos impulsivos da moléstia, que somente mais tarde, mercê de comoções violentas, se desvendou inteiramente nas manifestações físicas dos ataques. E se pudéssemos acompanhar a sua vida assistiríamos ao desdobramento contínuo do mal, que lhe imprimiu, como a outros sócios de desdita, um feitio original e interessante, definido por uma sucessão por demais eloquente de atos que, aparecendo intercalados por períodos de calma crescentemente reduzidos, constituem os pontos determinantes da curva inflexível em que o arrebatava a fatalidade biológica.

De feito, eram correntes entre os seus companheiros de armas os episódios frisantes que, de tempos a tempos, com ritmo inabalável, lhe interferiam a linha de uma carreira militar correta como poucas.

Fora longo rememorá-los, além do perigo de incidirmos no arquivar versões exageradas ou falsas.

À parte, porém, todos os casos duvidosos, definidos sempre pelo traço preponderante de vias de fato violentíssimas - aqui o ultraje, a rebencadas, de um médico militar, além a arremetida a faca, felizmente tolhida em tempo, contra um oficial argentino, por certa palavra mal compreendida — apontamos, de relance, os mais geralmente conhecidos.

Um, sobretudo, dera relevo à sua energia selvagem.

Foi em 1884, no Rio de Janeiro. Um jornalista, ou melhor, um alucinado, criara, agindo libérrimo graças à frouxidão das leis repressivas, escândalo permanente de insultos intoleráveis na Corte do antigo Império; e tendo respingado sobre o Exército parte das alusões indecorosas, que por igual abrangiam todas as classes, do último cidadão ao monarca, foi infelizmente resolvido por alguns oficiais, como supremo recurso, a justiça fulminante e desesperadora do linchamento.

Assim se fez. E entre os subalternos encarregados de executar a sentença - em plena rua, em pleno dia, diante da justiça armada pelos Comblains de toda a força policial em armas - figurava, mais graduado, o capitão Moreira César, ainda moço, à volta dos trinta anos, e tendo já em seus assentamentos, averbados, merecidos elogios por várias comissões exemplarmente cumpridas. E foi o mais afoito, o mais impiedoso, o primeiro talvez no esfaquear pelas costas a vítima, exatamente na ocasião em que ela, num carro, sentado ao lado de autoridade superior do próprio Exército, se acolhera ao patrocínio imediato das leis...

O crime acarretou-lhe a transferência para Mato Grosso, e dessa Sibéria canicular do nosso Exército tornou somente após a proclamação da República.

\section{Vimo-lo nessa época.}

Era ainda capitão e embora nunca houvesse arrancado da espada em combate, recordava um triunfador. Nos dias ainda vacilantes do novo regime, o governo parecia desejar ter perto de si aquele esteio firme - o homem para as crises perigosas e para as grandes temeridades. A sua figura de menino atravessava os quartéis e as ruas envolta de murmúrio simpático e louvaminheiro, comentando-lhe em lisonjarias os lances capitais da vida, acerca dos quais, entretanto, era de todo muda uma fé de ofício de burocracia inofensivo e tímido, repleta de encômios ao desempenho de missões pacíficas.

Por um contraste expressivo, nos documentos da profissão guerreira é que estava a placabilidade de uma existência acidentada, revolta e turbulenta em que, não raro, relampagueara a faca, ao lado da espada inteiramente virgem.

Esta saiu-lhe da bainha, afinal, nos últimos anos da existência. Em 1893, já coronel, porque galgara velozmente três postos em dois anos, ao declarar-se a Revolta da Armada, o marechal Floriano Peixoto destacou-o armado de poderes discricionários para Santa Catarina, como uma barreira à conflagração que se reanimara no Sul e ameaçava os Estados limítrofes. Seguiu; e em ponto algum do nosso território pesou tão firme e tão estrangulador o guante dos estados de sítios.

Os fuzilamentos que ali se fizeram, com triste aparato de imperdoável maldade, dizem-no de sobra. Abalaram tanto a opinião nacional que, ao terminar a revolta, o governo civil, recém-inaugurado, pediu contas de tais sucessos ao principal responsável. A resposta, pelo telégrafo, foi pronta. Um “não”, simples, seco, atrevido, cortante, um dardo batendo em cheio a curiosidade imprudente dos poderes constituídos, sem o atavio, sem o rodeio, sem a ressalva da explicação mais breve.

Meses depois chamaram-no ao Rio de Janeiro. 
Embarca com o seu batalhão, o $7^{\circ}$, num navio mercante; e em pleno mar, com surpresa dos próprios companheiros prende o comandante. Assaltara-o — sem que para tal houvesse o mínimo pretexto — a suspeita de uma traição, um desvio na rota, adrede disposto para o prender e aos soldados. $\mathrm{O}$ ato seria absolutamente inexplicável se não o caracterizássemos como aspecto particular da desorganização psíquica que o vitimava.

Não lhe diminuiu, contudo, o prestígio. Fez-se dono do batalhão que comandava; deu-lhe um pessoal que ultrapassava, de muito, o número regulamentar de praças, entre as quais — em manifesta violação da lei dezenas de crianças que não podiam carregar as armas; e, imperando incondicionalmente, organizou o melhor corpo do exército, porque nos longos intervalos lúcidos patenteava, francas, qualidades eminentes e raras de chefe disciplinador e inteligente, contrastando com os paroxismos da exaltação intermitente.

Estes tomaram-se, por fim, mais ostensivos e repetidos — num crescendo inflexível.

Nomeado para a expedição contra Canudos, estadeou-os numa série de desatinos, culminados afinal por uma catástrofe.

Vê-los-emos em breve, extremados por dois ímpetos de impulsivo: a partida caprichosa de Monte Santo, de improviso, com espanto de seu próprio estado-maior, precisamente na véspera do dia prefixo em detalhe para a marcha; e, três dias mais tarde, o arremesso contra o arraial, de mil e tantos homens exaustos de uma carreira de léguas, precisamente na véspera do dia marcado para o assalto.

Estes últimos fatos, e a sua identidade está no objetivarem a mesma nevrose, tiveram a intercorrência dos ataques.

\section{Foram uma revelação.}

Todos os acidentes singulares de sua existência desconexa, viu-se afinal que eram sinais comemorativos enfeixando uma diagnose única e segura...

Realmente, a epilepsia alimenta-se de paixões; avoluma-se no próprio expandir das emoções subitâneas e fortes; mas, quando, ainda larvada, ou traduzindo-se em uma alienação apenas afetiva, solapa surdamente as consciências, parece ter na livre manifestação daquelas um derivativo salvador atenuando os seus efeitos. De sorte que, sem exagero de frase, se pode dizer que há muitas vezes num crime, ou num lance raro de heroísmo, o equivalente mecânico de um ataque. Contido o braço homicida, ou imobilizado, de chofre, o herói no arremesso glorioso, o doente pode surgir, ex abrupto, sucumbindo ao acesso. Daí esses atos inesperados, incompreensíveis ou brutais, em que a vítima procura iludir instintivamente o próprio mal, buscando muitas vezes o crime como um derivativo à loucura.

Durante longo tempo numa semiconsciência de seu estado, numa série de delírios breves e fugazes, que ninguém percebe, que nem ela às vezes percebe, sente crescer a instabilidade da vida. E luta tenazmente. Os intervalos lúcidos fazem-se-lhe ponto de apoio à consciência vacilante à procura de motivos inibitórios numa ponderação cada vez mais penosa das condições normais ambientes. Aqueles, entretanto, a pouco e pouco se enfraquecem. A inteligência abalada afinal mal se subordina às condições exteriores ou relaciona os fatos e, em contínuo descair, baralha-os, perturbaos, inverte-os, deforma-os. O doente cai, então, no estado crepuscular, segundo uma expressão feliz, e condensa no cérebro, como se fosse a soma de todos os delírios anteriores, instável, pronto a desencadear-se em ações violentas, que o podem atirar no crime ou, acidentalmente, na glória, o potencial da loucura.

Cabe à sociedade, nessa ocasião, dar-lhe a camisa de força ou a púrpura. Porque o princípio geral da relatividade abrange as mesmas paixões coletivas. Se um grande homem pode impor-se a um grande povo pela influência deslumbradora do gênio, os degenerados perigosos fascinam com igual vigor as multidões tacanhas.

Ora, entre nós, se exercitava o domínio do caput mortuum das sociedades. Despontavam efêmeras individualidades singulares; e entre elas o coronel César destacava-se em relevo forte, como se a niilidade do seu passado salientasse melhor a energia feroz que desdobrara nos últimos tempos.

É cedo ainda para que se lhe defina a altitude relativa e a depressão do meio em que surgiu. Na apreciação dos fatos o tempo substitui o espaço para a focalização das imagens: o historiador precisa de certo afastamento dos quadros que contempla. 
Cerremos esta página perigosa.

\section{Primeira expedição regular}

Deferindo ao convite que lhe fora feito, o coronel Moreira César seguiu a 3 de fevereiro para a Bahia, levando o batalhão que comandava, o $7^{\circ}$ de Infantaria, entregue à direção do major Rafael Augusto da Cunha Matos; uma bateria do $2^{\circ}$ Regimento de Artilharia, comandada pelo capitão José Agostinho Salomão da Rocha; e um esquadrão do $9^{\circ}$ de Cavalaria, do capitão Pedreira Franco.

Era o núcleo da brigada de três armas, que se constituiu logo com a celeridade que as circunstâncias demandavam, ligando-se-lhe três outros corpos, desfalcados tolos: o $16^{\circ}$, que estava em S. João d'El-Rei, de onde abalou dirigido pelo coronel Sousa Meneses, com 28 oficiais e 290 praças; cerca de 140 soldados do $33^{\circ}$; o $9^{\circ}$, de Infantaria, do coronel Pedro Nunes Tamarindo e pequenos contingentes da força estadual baiana.

O chefe expedicionário não se demorou na Bahia. Recolhida toda a força que lá estava, prosseguiu imediatamente para Queimadas, onde, cinco dias apenas depois que partira da capital da República, a 8 de fevereiro, estava toda a expedição reunida - quase 1.300 combatentes, fartamente municiados, com 15 milhões de cartuchos e 70 tiros de artilharia.

A mobilização fora, como se vê, um prodígio de rapidez. Continuou rápida. Deixando em Queimadas, “ $1{ }^{a}$ base de operações”, sob o comando de um tenente, platônica guarnição de oitenta doentes e setenta crianças, que não suportavam o peso das mochilas, seguiu o grosso da tropa para a " $2^{\mathrm{a}}$ base de operações”, Monte Santo, onde a 20 estava pronta para a investida.

Chegara, porém, mal auspiciada. Um dia antes a enervação doentia do comandante explodira numa convulsão epileptiforme, em plena estrada, antes do sítio de Quirinquinquá; e fora de caráter tal que os cinco médicos do corpo de saúde previram uma reprodução de lastimáveis consequências. Os principais chefes de corpos, porém, bem que cientes de um diagnóstico, que implicava seriamente a firmeza e as responsabilidades do comando geral ante as condições severas da luta, forraram-se, cautelosos e tímidos, à menor deliberação a respeito.
O coronel Moreira César abeirava-se do objetivo da campanha condenado pelos próprios médicos que comandava.

É natural que não fossem as operações concertadas com a indispensável lucidez e que as inquinassem, desde o primeiro passo nos caminhos, todos os erros e inexplicáveis descuidos e inexplicável olvido de preceitos rudimentares, já rudemente corrigidos ou expostos com a maior clareza nos desastres anteriores. Nada se resolveu de acordo com as circunstâncias especialíssimas da empresa. Ficou dominando todas as decisões um plano único, um plano de delegado policial enérgico: lançar a marche-marche mil e tantas baionetas dentro de Canudos.

Isto no menor tempo possível. Os engenheiros militares Domingos Alves Leite e Alfredo do Nascimento, tenentes do Estado-maior de $1^{\text {a }}$ classe, adidos à brigada, tiveram uma semana para reconhecer a paragem desconhecida e áspera. Na exiguidade de tal prazo não lhes era possível a escolha de pontos estratégicos, que firmassem uma linha de operações indispensáveis. $\mathrm{O}$ vertiginoso mesmo dos levantamentos militares estava aquém dessa missão de afogadilho, adstrita a trianguladas fantásticas bases medidas a olho, visadas divagantes pelos topos indistintos das serras, distâncias averbadas nos ponteiros dos podômetros presos às botas dos operadores apressados. Estes esclareciam-se inquirindo os raros habitantes dos lugares percorridos: era o arquivar longuras calcadas numa unidade traiçoeira, a légua, de estimativa exagerada pelo amor-próprio do matuto vezado às caminhadas longas; rumos desesperadamente embaralhados ou linhas de ensaios em que um erro de cinco graus era um primor de rigorismo; informes sobre acidentes, contextura do solo e aguadas, de existência problemática e dúbia.

Subordinaram ao comandante o levantamento feito. Foi, sem maior exame, aprovado.

De acordo com ele escolheu-se a nova estrada. Envolvente a do Cambaio, pelo levante, e mais longa de nove ou dez léguas, tinha, ao que se figurava, a vantagem de se arredar da zona montanhosa. Largando de Monte Santo, as forças demandariam o arraial do Cumbe no rumo seguro de ESE, e, atingindo este, inflectindo, rota em cheio para o norte, fraldejando as abas da Serra de Aracati, em marcha contornante, a pouco e pouco rumando a NNO, iriam interferir no sítio do Rosário a antiga estrada de 
Maçacará. Escolhido este caminho não se cogitou de o transformar em linha de operações, pela escolha de dois ou três pontos defensáveis, garantidos de guarnições que, mesmo diminutas, pudessem estear a resistência, dado que houvesse um insucesso, um recuo ou uma retirada.

\section{Crítica}

Ninguém cogitava na mais passageira hipótese de um revés. A exploração realizada fora até um transigir dispensável com as velharias da estratégia: bastava o olhar perspícuo do guia, capitão Jesuíno, para aclarar a rota.

Sabia-se, no entanto, que esta atravessaria longos trechos de caatingas exigindo aberturas de picadas, e extenso areal de quarenta quilômetros onde, naquela quadra, na plenitude do estio, não se compreendia a viagem sem que os combatentes fossem arcando sob carregamento de água, a exemplo das legiões romanas na Tunísia. Para obviar este inconveniente, levaram uma bomba artesiana, como se fossem conhecidas as camadas profundas da terra pelos que lhe ignoravam a própria superfície, e houvesse, entre as fileiras, argutos rabdomantes capazes de marcar, com a varinha misteriosa, o ponto exato em que existisse o lençol líquido a aproveitar-se. Veremos a sua função mais longe.

Entretanto ia-se marchar o desconhecido, por veredas desfrequentadas, porque todas as travessias por ali se resumem no trecho de uma estrada secular, a de Bom Conselho a Jeremoabo, contornando e evitando pelo levante os agros tabuleiros que lhe demoram ao norte, e descem insensivelmente para o Vaza-Barris, formando no ligeiro divortium aquarum, entre este e o Itapicuru, desmedidos areais sem o mais exíguo regato, porque absorvem, numa sucção de esponja, os mais impetuosos aguaceiros.

A jornada pressupunha-se longa e inçada de tropeços: 150 quilômetros, um mínimo de 25 léguas, que valiam por uma lonjura décupla, ante o despovoamento e a maninhez da terra. Era natural que se garantisse ao menos a pretensa base de operações, para que se não insulasse inteiramente a tropa no deserto. Apesar disto, Monte Santo, com as suas péssimas condições de defesa, dominada pela serrania a prumo, de onde meia dúzia de inimigos podiam batê-la toda, a salvo, ficaria sob o comando do coronel Meneses com uma guarnição deficiente de poucas dezenas de praças. De sorte que os jagunços poderiam facilmente tomá-la, enquanto o resto da tropa seguisse para Canudos. Não o fizeram. Mas era de presumir que o fizessem, porque lá chegavam informes acordes todos no assegurar que os sertanejos se aparelhavam fortemente para a luta.

\section{Cresce a população de Canudos}

Eram certas as notícias.

Canudos aumentara em três semanas de modo extraordinário. A nova do último triunfo sobre a expedição Febrônio, avolumada pelos que a espalhavam, romanceada já de numerosos episódios, destruíra as últimas vacilações dos crentes que até então tinham temido procurar o falanstério de Antônio Conselheiro.

Como nos primeiros tempos da fundação, a todo o momento, pelo alto das colinas, apontavam grupos de peregrinos em demanda da paragem lendária - trazendo tudo, todos os haveres; muitos carregando em redes os parentes enfermos, moribundos ansiando pelo último sono naquele solo sacrossanto, ou cegos, paralíticos e lázaros, destinando-se ao milagre, à cura imediata, a um simples gesto de taumaturgo venerado. Eram, co mo sempre, toda a sorte de gente: pequenos criadores, vaqueiros crédulos e possantes, de parceria, na mesma congérie, com os vários tipos da mangalaça sertaneja; ingênuas mães de família, irmanadas a zabaneiras incorrigíveis e trêfegas. No coice dessas procissões, viam-se, invariavelmente, sem compartirem das litanias entoadas, estranhos, seguindo sós, como de sobrerolda ao movimento dos fiéis, os bandidos soltos - capangas em disponibilidade, procurando um teatro maior à índole aventureira e à valentia impulsiva. No correr do dia, pelas estradas de Calumbi, de Maçacará, de Jeremoabo e de Uauá, convergindo dos quadrantes, chegavam cargueiros repletos de toda a sorte de mantimentos, enviados diretamente a Canudos pelos adeptos que de longe o avitualhavam, em Vila Nova da Rainha, Alagoinhas, em todos os lugares. Havia abastança e um entusiasmo forte. 


\section{Como aguardam os jagunços a nova expedição}

Logo ao apontar da manhã distribuíam-se os trabalhos. Não faltavam braços; havia-os até de sobra. Destacavam-se piquetes vigilantes, de vinte homens cada um, ao mando de cabecilha de confiança, para vários pontos de acesso - em Cocorobó, junto à confluência do Macambira, na baixada das Umburanas e no alto da Favela, a fim de renderem os que ali haviam atravessado a noite, velando. Seguiam para as insignificantes plantações, estiradas pelas duas margens do rio, os que na véspera já tinham pago o tributo de se entregarem ao serviço comum. Dirigiam-se para as obras da igreja, outros; e outros - os mais ardilosos e vivos - para mais longe, para Monte Santo, para o Cumbe, para Queimadas, em comissões delicadas, indagando acerca dos novos invasores, confabulando com os fiéis que naquelas localidades se afrontavam com a vigilância das autoridades, adquirindo armamentos, ajeitando contrabandos afinal fáceis de serem feitos, espiando tudo, de tudo inquirindo cautelosamente.

E partiam felizes. Pelos caminhos fora passavam pequenos grupos ruidosos, carregando armas ou ferramentas de trabalho, cantando. Olvidavam os morticínios anteriores. No ânimo de muitos repontava a esperança de que os deixariam, afinal, na quietude da existência simples do sertão.

\section{Trincheiras}

Os chefes, porém, não se iludiam. Premunidos de cautelas, concertaram na defesa urgente. Pelos dias ardentes, viam-se os sertanejos esparsos sobre o alto dos cerros e à ourela dos caminhos, rolando, carregando ou amontoando pedras, rasgando a terra a picareta e a enxada numa faina incessante. Construíam trincheiras.

O sistema era, pela rapidez, um ideal de fortificação passageira: aberta cavidade circular ou elíptica, em que pudesse ocultar-se e mover-se à vontade o atirador, bordavam-na de pequenos espaldões de pedras justapostas, com interstícios para se enfiar o cano das espingardas. As placas de talcoxisto, facilmente extraídas com todas as formas desejadas, facilitavam a tarefa. Explicam o extraordinário número desses fojos tremendos que progredindo, regularmente intervalados, para todos os rumos, crivando a terra toda em roda de Canudos, semelhavam canhoneiras incontáveis de uma fortaleza monstruosa e sem muros. Eram locadas, cruzando os fogos sobre as veredas, de tal modo que, sobretudo nos longos trechos onde aquelas seguem aproveitando o leito seco dos riachos, tornavam dificílima a travessia à tropa mais robusta e ligeira. E como previssem que esta, procurando escapar àquelas passagens perigosas, volvesse aos lados assaltando e conquistando as trincheiras que as orlavam, fizeram próximas, no alto das barrancas, outras mais distantes e identicamente dispostas, em que se pudessem acolher e continuar o combate os atiradores repelidos. De sorte que, seguindo pelos caminhos ou abandonando-os, os antagonistas seriam sempre colhidos numa rede de balas.

É que os rebeldes dispensavam quaisquer ensinamentos para estes preparativos. A terra era um admirável modelo: serrotes empinando-se em redutos, rios escavando-se em passagens cobertas e fossos; e, por toda a parte, as caatingas trançadas em abatises naturais. Escolhiam os arbustos mais altos e frondosos. Trançavam-lhes jeitosamente os galhos interiores, sem lhes desfazer a fronde, de modo a se formar, dois metros sobre o chão, pequeno jirau, suspenso, capaz de suportar comodamente um ou dois atiradores invisíveis, ocultos na folhagem. Eram uma usança avoenga, aqueles mirantes singulares com os quais desde muito vezavam tocaiar os canguçus bravios. Os mutãs ${ }^{1}$ dos indígenas intercalavam-se, deste modo, destacadamente, completando o alinhamento das trincheiras. Ou então dispositivos mais sérios. Descobriam um cerro coroado de grandes blocos redondos, em acervos. Desentupiam as suas junturas e as largas brechas, onde viçavam cardos e bromélias; abriam-nas como postigos estreitos, mascarados de espessos renques de gravatás; limpavam depois os repartimentos interiores; e moviam-se, por fim, folgadamente, entre os corredores do monstruoso blocausse dominante sobre as várzeas e os caminhos, e de onde podiam, sem riscos, alvejar os mais remotos pontos.

\section{Armas}

Não ficavam nisto os preparativos. Reparavam-se as armas. No arraial estrugia a orquestra estridente das bigornas, à cadência dos malhos e marrões: enrijando e maleando as foices entortadas; aguçando e aceirando

\footnotetext{
${ }^{1}$ Mutã - espécie de palanque, sobre o qual se espera a caça.
} 
os ferrões buídos; temperando as lâminas largas das facas de arrasto, compridas como espadas; retesando os arcos, que lembram uma transição entre as armas dos selvagens e a antiga besta de polé; consertando a fecharia perra das velhas espingardas e garruchas. E das tendas abrasantes irrompia um ressoar metálico de arsenais ativos.

\section{Pólvora}

Não era suficiente a pólvora adquirida nas vilas próximas, faziam-na: tinham o carvão, tinham o salitre, apanhado à flor da terra mais para o norte, junto ao S. Francisco, e tinham, desde muito, o enxofre. O explosivo surgia perfeito, de uma dosagem segura, rivalizando bem com os que adotavam nas caçadas.

\section{Balas}

Não faltavam balas. A goela larga dos bacamartes aceitava tudo: seixos rolados, pedaços de pregos, pontas de chifres, cacos de garrafas, esquírolas de pedras.

\section{Lutadores}

Por fim não faltavam lutadores famanazes, cujas aventuras de pasmar corriam pelo sertão inteiro.

Porque a universalidade do sentimento religioso, de par com o instinto da desordem, ali agremiara não baianos apenas senão filhos de todos os Estados limítrofes. Entre o "jagunço” do S. Francisco e o “cangaceiro” do Cariris, surgiam, sob todos os matizes, os valentões tradicionais dos conflitos sertanejos, variando até então apenas no nome, nas sedições parceladas, dos “calangros”, dos "balaios” ou dos “cabanos”.

Correra nos sertões um toque de chamada...

\section{João Abade}

Dia a dia chegavam ao arraial singulares recém-vindos, absolutamente desconhecidos. Vinham “debaixo do cangaço”: a capanga atestada de balas e o polvarinho cheio; a garrucha de dois canos atravessada à cinta, de onde pendia a parnaíba inseparável; à bandoleira, o clavinote de boca-de-sino. Nada mais. Entravam pelo largo, sem que lhes indagassem a procedência, como se fossem antigos conhecidos. Recebia-os o astuto João Abade que, pleiteando-lhes parelhas na turbulência, tinha a ascendência de uma argúcia rara e uns laivos de superioridade mental, graças talvez à circunstância de haver estudado no liceu de uma das capitais do Norte, de onde fugira após haver assassinado a noiva, o seu primeiro crime. O certo é que os dominava e disciplinava. “Comandante da rua”, título inexplicável naquele labirinto de bitesgas, sem abandonar o povoado exercia-lhe absoluto domínio que estendia pela redondeza, num raio de cinco léguas em volta, percorrida continuamente pelas rondas velozes dos piquetes.

Obedeciam-no incondicionalmente. Naquela dispersão de ofícios, múltiplos e variáveis, onde ombreavam o tabaréu crendeiro e o facínora despejado, estabelecera-se raro entrelaçamento de esforços; e a mais perfeita conformidade de vistas volvidas para um objetivo único: reagir à invasão iminente.

Houve, todavia, segundo o revelaram alguns prisioneiros no termo da campanha, uma parada súbita na azáfama guerreira, um como sobressalto, estuporando a grei revoltosa e pondo-a a pique de dissolução repentina: foi quando, voltando dos diversos pontos os emissários, que tinham ido indagar sobre a marcha invasora, trouxeram, a par de informações seguras quanto ao número e armamentos dos soldados, o renome do novo comandante.

Imobilizou a atividade febril dos jagunços a síncope de um espanto extraordinário. Exagerara-se demais na distensão das mais extravagantes fantasias a temibilidade daquele. Era o Anti-Cristo, vindo jungir à derradeira prova os penitentes infelizes. Imaginaram-no herói de grande número de batalhas, quatorze como especificou um rude poeta sertanejo, no canto que depois consagrou à campanha; e prefiguraram a devastação dos lares, dias de torturas sem nome, a par duríssimos tratos. Canudos dissolvido a bala, a fogo, e a espada...

Deram-lhe um apelido lúgubre — “Corta-cabeças”...

Segundo depois se soube, nenhuma das expedições foi aguardada com ansiedade igual. Houve mesmo algumas deserções, rareando principalmente as fileiras que deviam tornar-se mais fortes, a dos adventícios perigosos que para lá iam não já sob o estímulo de uma crença 
senão pelo anelo dos desmandos e dos conflitos. Os piquetes, ao tornarem dos arredores, chegavam desfalcados de alguns daqueles sinistros companheiros.

Mas esse movimento de temor redundara em movimento seletivo. Expungira o arraial de incrédulos e tímidos. A grande maioria dos verdadeiros crentes permaneceu resignada.

\section{Procissões}

Desinfluído embora, o povo volvera-se para a última instância da fé religiosa. E não raro, então, atirando para o lado as armas emperradas, o arraial inteiro saía em longas procissões de penitência pelos descampados.

Cessaram, de chofre, os contingentes de peregrinos. Cessou o mourejar febril dos preparativos bélicos. Os piquetes que diariamente, ao clarear das manhãs, seguiam para diversos pontos, não mais passavam pelas veredas entoando as cantigas altas e festivas; embrenhavam-se, cautos, pelas moitas, quedando-se largas horas, silenciosos, vigilantes.

\section{Rezas}

Nesta situação aflitíssima, saiu a campo, alentando os combatentes robustos, mas apreensivos, a legião fragílima da beataria numerosa. Ao anoitecer, acesas as fogueiras, a multidão, genuflexa, prolongava além do tempo consagrado, as rezas, dentro da latada.

Esta, entressachada de ramas aromáticas de caçatinga, tinha, extremando-a, à porta do Santuário, uma pequena mesa de pinho coberta de toalha alvíssima.

Abeirava-a, ao findar dos terços, uma figura estranha.

Revestido da longa camisa de azulão, que lhe descia, sem cintura, desgraciosamente, escorrida pelo corpo alquebrado abaixo; torso dobrado, fronte abatida e olhos baixos, Antônio Conselheiro aparecia. Quedava longo tempo, imóvel e mudo, ante a multidão silenciosa e queda. Erguia lentamente a face macilenta, de súbito iluminada por olhar fulgurante e fixo. E pregava.

A noite descia de todo e o arraial repousava sob o império do evangelista humílimo e formidável..

\section{Capítulo II}

\section{Partida de Monte Santo}

Iam partir as tropas a 22 de fevereiro. E consoante a praxe, na véspera, à tarde, formaram numa revista em ordem de marcha para que se lhes avaliassem o equipamento e as armas.

A partida realizar-se-ia no dia subsequente, irrevogavelmente. Determinara-a a "ordem de detalhe".

Neste pressuposto alinharam-se os batalhões num quadrado, perlongando as faces do largo de Monte Santo.

Ali estavam: o $7^{\circ}$, com efetivo superior ao normal, comandado interinamente pelo major Rafael Augusto da Cunha Matos; o $9^{\circ}$, que pela terceira vez se aprestava à luta, ligeiramente desfalcado, sob o comando do coronel Pedro Nunes Tamarindo; frações do $33^{\circ}$ e $16^{\circ}$, dirigidas pelo capitão Joaquim Quirino Vilarim; a bateria de quatro Krupps do $2^{\circ}$ Regimento, comandada pelo capitão José Salomão Agostinho da Rocha; um esquadrão de cinquenta praças do $9^{\circ}$ de Cavalaria, ao mando do capitão Pedreira Franco; contingentes da polícia baiana, corpo de saúde chefiado pelo Dr. Ferreira Nina; e comissão de engenharia. Excetuavam-se setenta praças do $16^{\circ}$, que ficariam com o coronel Sousa Meneses guarnecendo a vila.

Eram ao todo 1.281 homens - tendo cada um 220 cartuchos nas patronas e cargueiros, à parte a reserva de 60 mil tiros no comboio geral.

Fez-se a revista. Mas contra a expectativa geral, ao invés da voz de ensarilhar armas e debandar, ressoou a corneta ao lado do comando em chefe, dando a de "coluna de marcha".

O coronel Moreira César, deixando depois, a galope, o lugar onde até então permanecera, tomou-lhe logo a frente.

Iniciava-se quase ao cair da noite a marcha para Canudos.

O fato foi de todo inesperado. Mas não houve o mais leve murmúrio nas fileiras. A surpresa, retratando-se em todos os olhares, não perturbou o 
rigor da manobra. Retumbaram os tambores na vanguarda; deslocaram-se sucessivamente as seções, desfilando, adiante, a dois de fundo, ao penetrarem o caminho estreito; abalou o trem da artilharia; rodaram os comboios...

Um quarto de hora depois, os habitantes de Monte Santo viam desaparecer, ao longe, na última curva da estrada, a terceira expedição contra Canudos.

\section{Primeiros erros}

A vanguarda chegou em três dias ao Cumbe sem o resto da força, que ficara retardada algumas horas - com o comandante retido numa fazenda próxima por outro ataque de epilepsia.

E na antemanhã de 26, tendo alcançado na véspera o sítio de Cajazeiras, a duas e meia léguas do Cumbe, abalaram rumo direto ao norte, para Serra Branca mais de três léguas na frente.

Esta parte do sertão, na orla dos tabuleiros que se dilatam até Jeremoabo, diverge muito das que temos rapidamente bosquejado. É menos revolta e é mais árida. Rareiam os cerros de flancos abruptos e estiram-se chapadas grandes. O aspecto menos revolto da terra, porém, encobre empeços porventura mais sérios. O solo arenoso e chato, sem depressões em que se mantenham, reagindo aos estios, as cacimbas salvadoras, é absolutamente estéril. E como as maiores chuvas ao caírem, longamente intervaladas, mal o embebem, prestes desaparecendo sorvidas pelos areais, cobre-o flora mais rarefeita transmudando-se as caatingas em caatanduvas.

Na plenitude do estio de novembro a março, a desolação é completa. Quem por ali se aventura tem a impressão de varar por uma roçada enorme de galhos secos e entrançados, onde a faúlha de um isqueiro ateia súbitos incêndios, se acaso estes não se alastram espontaneamente no fastígio das secas, nos meio-dias quentes, quando o Nordeste atrita rijamente as galhadas. Completa-se então a ação esterilizadora do clima, e por maneira tal que naquele trato dos sertões - sem um povoado e onde passam, rápidos, raros viajantes pela estrada de Jeremoabo a Bom Conselho inscrito em vasto círculo irregular tendo como pontos determinantes os povoados que o abeiram, do Cumbe ao sul, a Santo Antônio da Glória ao norte, de Jeremoabo a leste, a Monte Santo a oeste, se opera lentamente a formação de um deserto.

As árvores escasseiam. Dominando a vegetação inteira, quase exclusivos em certos trechos, enredam-se, em todos os pontos, mirrados arbúsculos de mangabeiras, único vegetal que ali medra sem decair, graças ao látex protetor que lhe permite, depois das soalheiras e das queimadas, cobrir de folhas e de flores os troncos carbonizados, à volta das estações propícias.

\section{Nova estrada}

Mas a expedição por ali enveredava na quadra mais imprópria. E tinha que caminhar, de arranco, sob temperatura altíssima que esgotava os soldados e não os insolava mercê da secura extrema dos ares, até o ponto prefixado, onde a existência de uma cacimba facultaria a alta.

A travessia foi penosamente feita. O terreno inconsistente e móvel fugia sob os passos aos caminhantes; remorava a tração das carretas absorvendo as rodas até ao meio dos raios; opunha, salteadamente, flexíveis barreiras de espinheirais, que era forçoso destramar a facão; e reduplicava, no reverberar intenso das areias, a adustão da canícula. De sorte que ao chegar, à tarde, à Serra Branca, a tropa estava exausta. Exausta e sequiosa. Caminhara oito horas sem parar, em pleno arder do Sol bravio do verão.

Mas para a sede inaturável, que resulta da quase completa depleção das veias esgotadas pelo suor, encontraram-se, ali, na profundura de uma cava, alguns litros d'água.

Fora previsto o transe, como vimos. Procurou-se cravar o tubo da bomba artesiana. A operação, porém - e os seus efeitos eram impacientemente aguardados — resultou inútil. Era inexequível. Ao invés de um bate-estacas que facilitasse a penetração da sonda, haviam conduzido aparelho de função inteiramente oposta, um macaco de levantar pesos.

Ante o singularíssimo contratempo, só havia alvitrar-se a partida imediata, malgrado a distância percorrida, para o sítio do Rosário, seis léguas mais longe.

A tropa combalida abalou à tarde. 
A noite colheu-a na marcha, feita ao brilho das estrelas, varando pelas veredas rendilhadas de espinho...

Calcula-se o que foi essa jornada de oito ou dez léguas, sem folga. Mil e tantos homens penetrando, quase em cambaleios, torturados de sede, acurvados sob as armas, em pleno território inimigo. O tropear soturno das fileiras, o estrépido dos reparos e carretas, os tinidos das armas, esbatiam-se na calada do ermo, e naquela assonância ilhada no silêncio se afogavam imperceptíveis estalidos nas macegas.

Ladeavam a tropa — em rastejamentos à ourela dos desvios - os espias dos jagunços.

Ninguém cuidava neles. Abatidos de um dia inteiro de viagem os expedicionários, deslembrados da luta, iam sob o anelo exclusivo dos pouso apetecido. Seguiam imprudentemente, de todo entregues ao tino e lealdade dos guias.

Mas afinal pararam, em plena estrada: alguns estropiados perdiam-se distanciados à retaguarda e os mais robustos mesmo a custo caminhavam. Foi uma alta breve, ilusório descanso: praças caídas ao longo dos caminhos, oficiais dormindo, os que dormiam, com as rédeas dos cavalos enleadas aos punhos. E reatada a marcha, na antemanhã seguinte, reconheceram que estavam na zona perigosa. Cinzas de fogueiras a cada passo encontradas e algumas ainda mornas; restos de repastos em que eram preexcelente vitualha jabutis assados e quartos de cabrito; rastros frescos na areia, entranhando-se tortuosamente nas caatingas, diziam que os sertanejos ali tinham estado, e passado também a noite, rodeando-os, invisíveis, nas rondas cautelosas.

Na Porteira Velha a vanguarda parece mesmo havê-los surpreendido, ocasionando precípite debandada. Ficaram junto à fogueira uma pistola de dois canos e um ferrão de vaqueiro.

O Rosário foi alcançado antes do meio-dia, ao tempo que caía violento e transitório aguaceiro, como soem sobrevir durante aquela quadra nos sertões. Aquele sítio, destinado a celebrizar-se no correr da campanha, era o que eram os demais das cercanias: uma ou duas casas pequenas de telha vã, sem soalho; ladeadas de uma cerca de achas, ou paus roliços; fronteando um terreno limpo com algumas árvores franzinas; e tendo, pouco distante, a cacimba ou a ipueira que determinou a escolha do local.

A expedição ali acampou. Estava no âmago do território inimigo; e, ao que se afigura, invadiram-na pela primeira vez as apreensões da guerra.

\section{Di-lo incidente expressivo.}

No dia $1^{\circ}$ de março, precisamente na hora em que outra chuva passageira e forte caía sobre a tropa desabrigada, estrugiram as notas de um alarma. O inimigo certo aproveitara o ensejo para sobressaltear os invasores, ligando-se ao furor dos elementos e surgindo naquele chuveiro, de improviso, armas disparadas no fragor da trovoada que abalava a altura...

Correndo e caindo, resvalando no chão escorregadio e encharcado; esbarrando-se em carreiras cruzadas sob o fustigar das bátegas, oficiais e praças procuravam a formatura impossível, vestindo-se, apresilhando cinturões e talins, armando-se às carreiras; surdos às discordes vozes de comando; alinhando seções e companhias ao acaso, num tumulto. E daquele enredamento de fileiras, rompeu aforradamente, de arremesso, um cavaleiro isolado, sem ordenanças, precipitando-se a galope entre os soldados tontos, e lançando-se pela estrada, na direção provável do inimigo, mal alcançado pelo engenheiro militar Domingos Leite.

\section{Era o coronel Moreira César.}

Felizmente o inimigo imaginário, a quem ia entregar-se, procurandoo naquela arremetida inútil, era um comboio de gêneros enviados por um fazendeiro amigo, das cercanias ${ }^{1}$.

Tirante este incidente o dia passou em completa paz, tendo vindo à tarde um correio de Monte Santo e cavalos para o esquadrão que até ali viajara em muares imprestáveis

E, na alta madrugada no dia 2, os batalhões marcharam para o Angico onde chegaram às 11 horas da manhã, acampando dentro do grande curral do sítio em abandono.

\footnotetext{
${ }^{1}$ Coronel da Guarda Nacional, José Américo C. de Souza Velho, dono dos sítios de
} "Caimbê" e "Olhos d’Água”. Foi quem aconselhou a estrada à expedição. 
Estava assente o plano definitivo da rota, adrede concebido de modo a diminuir o esfalfamento das marchas forçadas anteriores: descansando todo o resto do dia no rancho do Vigário a tropa abalaria, a 3, para o Angico, andando apenas uns oito quilômetros, e ali, novamente descansando, pernoitaria. Decampando a 4, iria diretamente sobre Canudos, depois de caminhar pouco mais de légua e meia. Como estavam em pleno território inimigo, tomaram-se dispositivos para garantir o acampamento, rodeando-o de piquetes e sentinelas circulares.

O coronel César internou-se na caatinga próxima, onde mandou armar a sua barraca. Ali, não ocultou aos chefes dos corpos a segurança absoluta na vitória. Apresentaram-lhe vários alvitres atinentes a rodearem de maiores resguardos a investida, um dos quais, aventado pelo comandante do $7^{\circ}$, impunha a modificação preliminar da ordem até então adotada na marcha. Sugeria a divisão em duas, da coluna até então unida, destinandose uma forte vanguarda para o reconhecimento e o primeiro combate; entrando a outra na ação, como reforço. Desse modo, se por qualquer circunstância se verificassem poderosos os recursos do adversário, tornarse-ia factível um recuo em ordem para Monte Santo, onde se reorganizariam, aumentadas as forças.

Contra o que era de esperar, o chefe expedicionário não desadorou o alvitre. A tropa prosseguiria a 3, pelo amanhecer, adstrita a um plano lucidamente traçado.

\section{Em marcha para o Angico}

Entretanto ao marchar para o Angico levava uma ordem que era a mesma da partida do Cumbe: na frente um piquete de exploradores montados; um guia, Manuel Rosendo, experimentado e bravo, e a comissão de engenharia; uma companhia de atiradores do $7^{\circ}$, comandada pelo tenente Figueira; a ala direita do $7^{\circ}$ com o major Cunha Matos, marchando de costado, levando no centro o respectivo comboio de munições; $1^{\mathrm{a}}$ a Divisão do $2^{\circ}$ Regimento, sob a imediata direção de Salomão da Rocha; ala esquerda do $7^{\circ}$, dirigida pelo capitão Alberto Gavião Pereira Pinto; $2^{a}$ Divisão de Artilharia, do $1^{\circ}$ tenente Marcos Pradel de Azambuja; ala direita do $9^{\circ}$, sob o mando do coronel Tamarindo, separada da esquerda, dirigida pelo capitão Felipe Simões, pelo respectivo comboio.
À retaguarda o corpo de saúde; contingentes do $16^{\circ}$, do capitão Quirino Vilarim; e o comboio geral guardado pela polícia baiana.

Por último a cavalaria. O coronel César, na vanguarda, ia entre a companhia de atiradores e a ala direita do $7^{\circ}$.

Tinham partido às cinco horas da manhã. Alcançavam a região característica dos arredores de Canudos: fortemente riçada de serranias vestidas de vegetação raquítica, de cardos e bromélias; recortada de regatos derivando em torcicolos - num crescente enrugamento da terra cada vez mais adversa, onde a vinda recente das chuvas ainda não estendera a vestimenta efêmera da flora revivente, velando-lhe os pedroiços e os algares.

Os chuvisqueiros da véspera, como sucede na plenitude do estio, haviam passado sem deixarem traços. O solo requeimado absorvera-os e repelira-os, permanecendo ressequido e agro. Em roda, até aonde se estendia o olhar, pelo bolear dos cerros, pelas rechãs que se estiram nos altos, pelas várzeas que os circuitam, pelas serranias de flancos degradados, por toda a parte, o mesmo tom nas paisagens a um tempo impressionadoras e monótonas: a natureza imóvel, caída num grande espasmo, sem uma flor sobre as ramagens nuas, sem um bater de asas nos ares quietos e serenos...

A coluna em marcha, estirada numa linha de três quilômetros, cortava-a em longo risco negro e tortuoso.

Viam-se, adiante e próximas, ao norte, as últimas serranias que rodeiam Canudos, sem que este abeirar-se do objetivo da luta conturbasse o ânimo dos soldados.

\section{Psicologia do soldado brasileiro}

Seguiam tranquilamente a passo ordinário e seguro.

Da extensa linha da brigada evolava-se um murmúrio vago de milhares de sílabas emitidas à meia voz, aqui, ali, repentinamente salteadas de risos joviais. Os nossos soldados estadeavam o seu atributo preeminente naquela alacridade singular com que se aproximavam do inimigo. Homens de todas as cores, amálgamas de diversas raças, parece que no sobrevir dos lances perigosos e no abalo de emoções fortíssimas lhes preponderam, 
exclusivas, no ânimo, por uma lei qualquer de psicologia coletiva, os instintos guerreiros, a imprevidência dos selvagens, a inconsciência do perigo, o desapego à vida e o arremesso fatalista para a morte.

Seguem para a batalha como para algum folguedo turbulento. Intoleráveis na paz que os molifica, e infirma, e relaxa; inclassificáveis nas paradas das ruas, em que passam sem garbo, sem aprumo, corcundas sob a espingarda manejada, a guerra é o seu melhor campo de instrução e o inimigo o instrutor predileto, transmudando-os em poucos dias, disciplinando-os, enrijando-os, dando-lhes em pouco tempo, nos exercícios extenuadores da marcha e do combate, o que nunca tiveram nas capitais festivas - a altivez do porte, a segurança do passo, a precisão do tiro, a celeridade das cargas. Não sucumbem à provação. São inimitáveis no caminhar dias a fio pelos mais malgrados caminhos. Não boquejam a reclamação mais breve nas piores aperturas; e nenhuns se lhes emparelham no resistir à fome, atravessando largos dias à brisa, segundo o dizer de seu calão pinturesco. Depois dos mais angustiosos transes, vimos valentes escaveirados meterem à bulha o martírio e troçarem, rindo, com a miséria.

No combate, certo, nenhum é capaz de entrar e sair, como o prussiano, com um podômetro preso à bota — é desordenado, é revolto, é turbulento, é um garoto heroico e terrível, arrojando contra o adversário, de par com a bala ou a pranchada, um dito zombeteiro e irônico. Por isto se imprópria ao desdobramento das grandes massas nas campanhas clássicas. Manietam-no as formaturas corretas. Estonteia-o o mecanismo da manobra complexa. Tortura-o a obrigação de combater adstrito ao ritmo das cornetas; e de bom grado obediente aos amplos movimentos da estratégia, seguindo, impassível, para os pontos mais difíceis, quando o inimigo lhe chega à ponta do sabre quer combater a seu modo. Bate-se, então, sem rancor, mas estrepitosamente, fanfarrão, folgando entre as cutiladas e as balas, arriscando-se doidamente, barateando a bravura. Fá-lo, porém, de olhos fixos nos chefes que o dirigem e de cuja energia parece viver exclusivamente. De sorte que a mínima vacilação daqueles tem, de chofre, extintas todas as ousadias e cai num abatimento instantâneo salteado de desânimos invencíveis.

Ora, naquela ocasião, tudo vaticinava aos expedicionários a vitória. Com tal chefe não havia cogitar em reveses. E endireitavam firmes para a frente, impacientes por virem às mãos com o adversário esquivo. Vendiam escandalosamente a pele do urso sertanejo. Gizavam antecipadas façanhas; coisas de pasmar, depois, aos ouvintes crédulos e tímidos; cenas jocotrágicas - lá dentro, na tapera monstruosa, quando a varressem a tiro. E faziam planos bizarros, projetos prematuros, iniciados todos por uma preliminar ingênua: “Quando eu voltar...”.

Alguns, às vezes, saíam-se com um pensamento extravagante, e no burburinho confuso passava, sulcando-o, um ondular de risos mal contidos...

Além disto, aquela manhã resplandecente os alentava. O belo firmamento dos sertões arqueava-se sobre a terra — irisado — passando em transições suavíssimas do zênite azul à púrpura deslumbrante do oriente.

Ademais o adversário que deixara livre até ali o caminho, desdenhando os melhores trechos para o cortar, ameaçava-os de um único contratempo sério: o toparem vazio o arraial sedicioso.

Assustava-os esse desapontamento provável; a campanha transformada em passeio militar penoso; a volta inglória, sem o dispêndio de um cartucho. 


\section{Capítulo III}

\section{Pitombas}

Iam nestas disposições admiráveis quando chegaram a Pitombas.

O pequeno ribeirão que ali corre, recortando fundamente o solo, ora ladeia, ora atravessa a estrada, interrompendo-a, serpeante. Por fim a deixa antes de chegar ao sítio a que dá o nome, arqueando-se em volta longa, um quase semicírculo de que o caminho é a corda.

\section{O primeiro encontro}

Tomou por esta a tropa. E quando a vanguarda lhe atingiu o meio, estourou uma descarga de meia dúzia de tiros.

\section{Era afinal o inimigo.}

Algum piquete de sobre-ronda à expedição, ou ali aguardando-a, que aproveitara a conformação favorável do terreno para um ataque instantâneo, ferindo-a de soslaio, e furtando-se a seguro pelas passagens cobertas das ribanceiras do rio.

Mas atirara com firmeza: abatera, mortalmente ferido, um dos subalternos da companhia de atiradores, o alferes Poly, além de seis a sete soldados. Descarregara as armas e fugira a tempo de escapar à réplica, que foi pronta.

Para logo conteirados os canhões da divisão Salomão, a metralha explodiu no matagal rasteiro. Os arbustos dobraram acamando-se, como à passagem de ventanias ríspidas. Varreram-no.

Logo depois nos ares, ainda ressoantes dos estampidos, correu triunfalmente o ritmo de uma carga, e destacando-se, desenvolvida em atiradores, do grosso da coluna, a ala direita do $7^{\circ}$ lançou-se na direção do inimigo, atufando-se nas macegas, a marche-marche, roçando-as a baioneta.

Foi uma diversão gloriosa e rápida.
O inimigo furtara-se ao recontro. Volvidos minutos, a ala tornou à linha da coluna entre aclamações, enquanto o antigo toque de "trindades", era agora o sinal da vitória, soava em vibrações altíssimas. O comandante em chefe abraçou, num lance de alegria sincera, o oficial feliz que dera aquele repelão valente no antagonista, e considerou auspicioso o encontro. Era quase para lastimar tanto aparelho bélico, tanta gente, tão luxuosa encenação em campanha destinada a liquidar-se com meia dúzia de disparos.

\section{“Esta gente está desarmada...”}

As armas dos jagunços eram ridículas. Como despojo, os soldados encontraram uma espingarda pica-pau, leve e de cano finíssimo, sob a barranca. Estava carregada. O coronel César, mesmo a cavalo, disparou-a para o ar. Um tiro insignificante, de matar passarinho.

— Esta gente está desarmada... — disse tranquilamente.

E reatou-se a marcha, mais rápida agora, a passos estugados, ficando em Pitombas os médicos e feridos, sob a proteção do contingente policial e resto da cavalaria. O grosso dos combatentes perdeu-se logo adiante, em avançada célere. Quebrara-se, de vez, o encanto do inimigo. Os atiradores e flanqueadores, na vanguarda, batiam o caminho e embrenhavam-se nas caatingas, rastreando os espias que acaso por ali houvesse, desinçando-as das tocaias prováveis, ou procurando alcançar os fugitivos que endireitavam para Canudos.

O recontro fora um choque galvânico. A tropa, a marche-marche, prosseguia, agora, sob a atração irreprimível da luta, nessa ebriez mental perigosíssima, que estonteia o soldado duplamente fortalecido pela certeza da própria força e a licença absoluta para as brutalidades máximas.

\section{O pânico e a bravura}

Porque num exército que persegue há o mesmo automatismo impulsivo dos exércitos que fogem. O pânico e a bravura doida, o extremo pavor e audácia extrema, confundem-se no mesmo aspecto. O mesmo estonteamento e o mesmo tropear precipitado entre os maiores obstáculos, e a mesma vertigem, e a mesma nevrose torturante abalando as fileiras, e a 
mesma ansiedade dolorosa, estimulam e alucinam com idêntico vigor o homem que foge à morte e o homem que quer matar. É que um exército é, antes de tudo, uma multidão, “acervo de elementos heterogêneos em que basta irromper uma centelha de paixão para determinar súbita metamorfose, numa espécie de geração espontânea em virtude da qual milhares de indivíduos diversos se fazem um animal único, fera anônima e monstruosa caminhando para dado objetivo com finalidade irresistível”. Somente a fortaleza moral de um chefe pode obstar esta transfiguração deplorável, descendo, lúcida e inflexível, impondo uma diretriz em que se retifique o tumulto. Os grandes estrategistas têm, instintivamente, compreendido que a primeira vitória a alcançar nas guerras está no debelar esse contágio de emoções violentas e essa instabilidade de sentimentos que com a mesma intensidade lançam o combatente nos mais sérios perigos e na fuga. Um plano de guerra riscado a compasso numa carta exige almas inertes máquinas de matar — firmemente encarrilhadas nas linhas que preestabelece.

Mas estavam longe deste ideal sinistro os soldados do coronel Moreira César e este ao invés de reprimir a agitação ia ampliá-la. Far-se-ia o expoente da nevrose.

Sobreviera, entretanto, ensejo para normalizar a situação.

Chegaram a Angico, ponto determinado da última parada. Ali, estatuíra-se em detalhe, repousariam. Decampariam pela manhã do dia seguinte: cairiam sobre Canudos após duas horas de marcha. O ímpeto que trazia a tropa, porém, teve uma componente favorável nas tendências arrojadas do chefe. Obsediava-o o anseio de vir logo às mãos com o adversário.

A alta no Angico foi de um quarto de hora; o indispensável para mandar tocar a oficiais; reuni-los sobre pequena ondulação dominante sobre os batalhões, ofegantes em torno; e apresentar-lhes, olvidando o axioma de que nada se pode tentar com soldados fatigados, o alvitre de prosseguirem naquela arremetida até o arraial:

- Meus camaradas! como sabem, estou visivelmente enfermo. Há muitos dias não me alimento; mas Canudos está muito perto... Vamos tomálo!
Foi aceito o alvitre.

— Vamos almoçar em Canudos! — disse, alto.

Respondeu-lhe uma ovação da soldadesca.

A marcha prosseguiu. Eram onze horas da manhã.

Dispersa na frente a companhia de atiradores revolvia as moiteiras, dentre as quais, distantes, raros tiros, espaçados, de adversários em fuga, estrondavam, como se tivessem o intuito único de a atraírem e ao resto da tropa; espelhando estratégia ardilosa, armada a arrebatá-la até ao arraial naquelas condições desfavoráveis — combalida e exausta de uma marcha de seis horas.

\section{“Em acelerado!"}

Há um atestado iniludível desta arrancada louca, encurtando o fôlego dos soldados perto da batalha: para que se não remorasse o passo de carga da infantaria, foi permitido às praças arrojarem de si as mochilas, cantis e bornais, e todas as peças do equipamento, excluídos os cartuchos e as armas, que a cavalaria, à retaguarda, ia recolhendo, à medida que encontrava.

Neste avançar desapoderado, galgaram a achada breve do alto das Umburanas. Canudos devia estar muito perto, ao alcance da artilharia. A força fez alto...

\section{Dois cartões de visita ao Conselheiro}

O guia Jesuíno, consultado, apontou com segurança a direção do arraial. Moreira César pôs em batalha a divisão Pradel e, graduada a alça de mira para três quilômetros, mandou dar dois tiros segundo o rumo indicado.

— Lá vão dois cartões de visita ao Conselheiro... - disse, quase jovial, com o humorismo superior de um forte.

A frase passou como um frêmito entre as fileiras. Aclamações. Renovou-se a investida febrilmente. 
O Sol dardejava a prumo. Transpondo os últimos acidentes fortes do terreno, os batalhões abalaram, dentro de uma nuvem pesada e cálida, de poeira.

De súbito, surpreendeu-os a vista de Canudos.

Estavam no alto da Favela.

\section{Um olhar sobre Canudos}

Ali estava, afinal, a tapera enorme que as expedições anteriores não haviam logrado atingir.

Aparecia, de improviso, toda, numa depressão mais ampla da planície ondulada. E no primeiro momento, antes que o olhar pudesse acomodar-se àquele montão de casebres, presos em rede inextricável de becos estreitíssimos e dizendo em parte para a grande praça onde se fronteavam as igrejas, o observador tinha a impressão exata de topar, inesperadamente, uma cidade vasta. Feito grande fosso escavado, à esquerda, no sopé das colinas mais altas, o Vaza-Barris abarcava-a e inflectia depois, endireitando em cheio para leste, rolando lentamente as primeiras águas da enchente. A casaria compacta em roda da praça a pouco e pouco se ampliava, distendendo-se, avassalando os cerros para leste e para o norte até às últimas vivendas isoladas, distantes, como guaritas dispersas — sem que uma parede branca ou telhado encaliçado quebrasse a monotonia daquele conjunto assombroso de 5 mil casebres impactos numa ruga da terra. As duas igrejas destacavam-se, nítidas. A nova, à esquerda do observador ainda incompleta, tendo aprumadas as espessas e altas paredes mestras, envolta de andaimes e bailéus, mascarada ainda de madeiramento confuso de traves, vigas e baldrames, de onde se alteavam as pernas rígidas das cábreas com os moitões oscilantes; - erguida dominadoramente sobre as demais construções, assoberbando a planície extensa; e ampla, retangular, firmemente assente sobre o solo, patenteando nos largos muros grandes blocos dispostos numa amarração perfeita — tinha, com efeito, a feição completa de um baluarte formidável. Mais humilde, construída pelo molde comum das capelas sertanejas, enfrentava-a a igreja velha. E mais para a direita, dentro de uma cerca tosca, salpintado de cruzes pequenas e mal feitas - sem um canteiro, sem um arbusto, sem uma flor — aparecia um cemitério de sepulturas rasas, uma tibicuera triste. Defrontando-as, do outro lado do rio, breve área complanada contrastava com o ondear colinas estéreis: algumas árvores esparsas, pequenos renques de palmatórias rutilantes e as ramagens virentes de seis pés de quixabeiras davam-lhe o aspecto de um jardim agreste. Aí caía a encosta de um esporão do morro da Favela, avantajando-se até ao rio, onde acabava em corte abrupto. Estes últimos rebentos da serrania tinham a denominação apropriada de Pelados, pelo desnudo das faldas. Acompanhando o espigão na ladeira, que para eles descamba em boléus, via-se, a meio caminho, uma casa em ruínas, a Fazenda Velha. Sobranceava-a um socalco forte, o Alto do Mário.

No fastígio da montanha, a tropa.

\section{Chegada da força}

Chegaram primeiro a vanguarda do $7^{\circ}$ e a artilharia, repulsando violento ataque pela direita, enquanto o resto da infantaria galgava as últimas ladeiras. Mal atentaram para o arraial. Os canhões alinharam-se em batalha, ao tempo que chegavam os primeiros pelotões embaralhados e arfando - e abriram o canhoneio disparando todos a um tempo, em tiros mergulhantes.

Não havia errar o alvo desmedido. Viram-se os efeitos das primeiras balas em vários pontos; explodindo dentro dos casebres e estraçoando-os, e enterroando-os; atirando pelos ares tetos de argilas e vigamentos em estilhas; pulverizando as paredes de adobes; ateando os primeiros incêndios...

Em breve sobre a casaria fulminada se enovelou e se adensou, compacta, uma nuvem de poeira e de fumo, cobrindo-a.

Não a divisou mais o resto dos combatentes. O troar solene da artilharia estrugia os ares; reboava longamente por todo o âmbito daqueles ermos, na assonância ensurdecedora dos ecos refluídos das montanhas...

\section{Rebate}

Mas, passados minutos, começaram a ouvir-se, nítidas dentro da vibração dos estampidos, precípites vozes argentinas. O sino da igreja velha batia, embaixo, congregando os fiéis para a batalha. 
Esta não se travara ainda.

À parte ligeiro ataque de flanco, feito por alguns guerrilheiros contra a artilharia, nenhuma resistência tinham oposto os sertanejos. As forças desenvolveram-se pelo espigão aladeirado, sem que uma só descarga perturbasse o desdobramento; e a fuzilaria principiou, em descargas rolantes e nutridas, sem pontarias. Oitocentas espingardas arrebentando, inclinadas, tiros rasantes, pelo tombador do morro...

Entre os claros do fumo lobrigava-se o arraial. Era uma colmeia alarmada: grupos inúmeros, dispersos, entrecruzando-se no largo, derivando às carreiras pelas barrancas do rio, dirigindo-se para as igrejas, rompendo, sopesando as armas, dos becos; saltando pelos tetos...

Alguns pareciam em fuga, ao longe, no extremo do arraial, pervagantes na orla das caatingas, desaparecendo no descair das colinas. Outros aparentavam incrível tranquilidade, atravessando a passo tardo a praça, alheios ao tumulto e às balas respingadas da montanha.

Toda uma companhia do $7^{\circ}$, naquele momento, fez fogo, por alguns minutos, sobre um jagunço, que vinha pela estrada de Uauá. E o sertanejo não apressava o andar. Parava às vezes. Via-se o vulto impassível aprumarse ao longe considerando a força por instantes, e prosseguir depois, tranquilamente. Era um desafio irritante. Surpreendidos, os soldados atiravam nervosamente sobre o ser excepcional, que parecia comprazer-se em ser alvo de um exército. Em dado momento ele sentou-se à beira do caminho e pareceu bater o isqueiro, acendendo o cachimbo. Os soldados riram. O vulto levantou-se e encobriu-se, lento e lento, entre as primeiras casas.

Dali nem um tiro partira. Diminuíra a agitação da praça. Cortavam-na os últimos retardatários. Viram-se passar, correndo, carregando ou arrastando pelo braço crianças, as últimas mulheres, na direção da latada, procurando o anteparo dos largos muros da igreja nova.

\section{Capítulo IV}

\section{A ordem de batalha}

Por fim emudeceu o sino.

A força começou a descer, estirada pelas encostas e justapostas às vertentes. Deslumbrava num irradiar de centenares de baionetas. Considerando-a o chefe expedicionário disse ao comandante de uma das companhias do $7^{\circ}$, junto ao qual se achava:

— Vamos tomar o arraial sem disparar mais um tiro!... à baioneta !

Era uma hora da tarde.

Feita a descida, a infantaria desenvolveu-se, em parte, no vale das quixabeiras, estremada à direita pelo $7^{\circ}$, que se alinhara segundo o traçado do Vaza-Barris, e à esquerda pelos $9^{\circ}$ e $16^{\circ}$ mal distendidos em terreno impróprio. A artilharia, no centro, sobre o último esporão dos morros avançado e a prumo sobre o rio, fronteiro e de nível com as cimalhas da igreja nova - fez-se o eixo desta tenalha prestes a fechar-se, apertando os flancos do arraial.

Era a mais rudimentar das ordens de combate: a ordem paralela simples, feita para os casos excepcionalíssimos de batalhas campais, em que a superioridade do número e da bravura, excluindo manobras mais complexas, permitam, em terreno uniforme, a ação simultânea e igual de todas as unidades combatentes.

\section{O terreno. Crítica}

Ali era inconceptível. Centralizada pela eminência onde estavam os canhões, a frente do assalto tinha, ao lado umas de outras, formas topográficas opostas; à direita, breve área de nível, facultando investida fácil porque o rio, naquele ponto, além de raso, corre entre bordas deprimidas; à esquerda, a terra mais revolta descaindo em recostos resvalantes e separada do arraial por um fosso profundo. A observação mais rápida indicava, porém, que estas disposições da extrema esquerda, sendo de todo desfavoráveis para os lutadores que devessem percorrê-las rapidamente correndo para o assalto, eram, por outro lado, elemento tático 
de primeira ordem para uma reserva que ali estacionasse, de prontidão, destinando-se a uma diversão ligeira, ou a intervir oportunamente, segundo as modalidades ulteriores do recontro. Deste modo, o relevo geral do solo ensinava por si mesmo, a ordem oblíqua, simples ou reforçada numa das alas, e, ao invés do ataque simultâneo, o ataque parcial pela direita firmemente apoiado pela artilharia, cujo efeito, atirando a cerca de pouco mais de cem metros do inimigo, seria fulminante.

Além disto, não havia mais surpresas naquela luta e, caso o adversário desdobrasse, de súbito, imprevistos recursos de defesa, as tropas de reforço, agindo fora do círculo tumultuário do combate, poderiam mais desafogadamente mover-se, segundo as eventualidades emergentes, em manobras decisivas, visando objetivos firmes. O coronel Moreira César, porém, desdenhara essas condições imperiosas e, arrojando à batalha toda a sua gente, parecia contar menos com a bravura do soldado e competência de uma oficialidade leal que com uma hipótese duvidosa: o espanto e o terror dos sertanejos em fuga, colhidos de improviso por centenares de baionetas. Revelou - claro - este pensamento injustificável, em que havia a insciência de princípios rudimentares da sua arte de par com o olvido de acontecimentos recentes; e cumulou tal deslize planeando a mais desastrosa das disposições assaltantes.

De feito, acometendo a um tempo por dois lados, os batalhões, de um e outro extremo, carregando convergentes para um objetivo único, fronteavam-se a breve trecho, trocando entre si as balas destinadas ao jagunço. Enquanto a artilharia, podendo a princípio bombardear as igrejas e centro do povoado, a pouco e pouco ia tendo restringido o âmbito de sua ação, à medida que avançavam aqueles, até perdê-la de todo, obrigada a emudecer na fase aguda da peleja generalizada, fugindo ao perigo de atirar sobre os próprios companheiros, indistintos com os adversários dentro daquele enredamento de casebres.

A previsão de tais inconvenientes, entretanto, não requeria vistas aquilinas de estrategista emérito. Revelaram-se nos primeiros minutos da ação.

\section{Cidadela-mundéu}

Esta foi iniciada heroicamente, abalando toda a tropa ao ressoar das cornetas de todos os corpos ao tempo que, vibrando de novo o sino da igreja velha, uma fuzilaria intensa irrompia das paredes e tetos das vivendas mais próximas ao rio e estrondavam, numa explosão única, os bacamartes dos guerrilheiros adensados dentro da igreja nova.

Favorecido pelo terreno, o $7^{\circ}$ Batalhão marchou em acelerado, sob uma saraivada de chumbo e seixos rolados, até à borda do rio. Em breve, vingando a barranca oposta, viram-se à entrada da praça os primeiros soldados, em grupos, sem coisa alguma que lembrasse a formatura do combate. Alguns ali mesmo tombaram ou rolaram na água, arrastados na corrente, que se listrava de sangue. A maioria avançou, batida de soslaio e de frente. Na extrema esquerda uma ala do $9^{\circ}$, vencendo as dificuldades da marcha cheia de tropeços, tomara posição à retaguarda da igreja nova, enquanto o $16^{\circ}$ e a ala direita do $7^{\circ}$ investiam pelo centro. $\mathrm{O}$ combate desenrolou-se logo em toda a plenitude, resumindo-se naquele avançar temerário. Não teve, depois, a evolução mais simples, ou movimento combinado, que revelasse a presença de um chefe.

Principiou a fracionar-se em conflitos perigosos e inúteis, numa dissipação inglória do valor. Era inevitável. Canudos, entretecido de becos de menos de dois metros de largo, trançados, cruzando-se em todos os sentidos, tinha ilusória fragilidade nos muros de taipa que o formavam. Era pior que uma cidadela inscrita em polígonos ou blindada de casamatas espessas. Largamente aberto aos agressores que podiam derruí-lo a coices de arma, que podiam abater-lhe a pulso as paredes e tetos de barro, ou varálo por todos os lados, tinha a inconsistência e a flexibilidade traiçoeira de uma rede desmesurada. Era fácil investi-lo, batê-lo, dominá-lo, varejá-lo, aluí-lo; - era dificílimo deixá-lo. Completando a tática perigosa do sertanejo, era temeroso porque não resistia. Não opunha a rijeza de um tijolo à percussão e arrebentamento das granadas, que se amorteciam sem explodirem, furando-lhe de uma vez só dezenas de tetos. Não fazia titubear a mais reduzida seção assaltante, que poderia investi-lo, por qualquer lado, depois de transposto o rio. Atraía os assaltos; e atraía irreprimivelmente o ímpeto das cargas violentas, porque a arremetida dos invasores, embriagados por vislumbres de vitória, e disseminando-se, divididos pelas 
suas vielas em torcicolos, lhe era o recurso tremendo de uma defesa surpreendedora.

Na história sombria das cidades batidas, o humílimo vilarejo ia surgir com um traço de trágica originalidade.

$$
\text { Intacto - era fragílimo; feito escombros — formidável. }
$$

Rendia-se para vencer, aparecendo, de chofre, ante o conquistador surpreendido, inexpugnável e em ruínas. Porque a envergadura de ferro de um exército, depois de o abalar e desarticular todo, esmagando-o, tornandoo montão informe de adobes e madeiras roliças, se sentia inopinadamente manietada, presa entre tabiques vacilantes de pau a pique e cipós, à maneira de uma suçuarana inexperta agitando-se, vigorosa e inútil, nas malhas de armadilha bem feita.

A prática venatória dos jagunços inspirara-lhes, talvez, a criação pasmosa da “cidadela-mundéu”...

Ora, as tropas do coronel Moreira César faziam-na desabar sobre si mesmas.

\section{Conflitos parciais}

A princípio, transposto o Vaza-Barris, a despeito de algumas baixas, o acometimento figurara-se fácil. Um grupo, arrastado por subalternos valentes, arrancara atrevidamente contra a igreja nova, sem efeito algum compensando-lhe o arrojo, perdendo dois oficiais e algumas praças. Outros, porém, contornando aquele núcleo resistente, lançaram-se às primeiras casas marginais ao rio. Tomaram-nas e incendiaram-nas; enquanto os que as guarneciam fugiam, adiante, em busca de outros abrigos. Perseguiramnos. E nesse perseguir tumultuário, realizado logo nos primeiros minutos do combate, começou a esboçar-se o perigo único e gravíssimo daquele fossado monstruoso; os pelotões dissolviam-se. Entalavam-se nas vielas estreitas, enfiando a dois de fundo por ali dentro, atropeladamente. Torciam centenares de esquinas que se sucediam de casa em casa; dobravam-nas em desordem, de armas suspensas uns, atirando outros ao acaso, à toa, para a frente; e dividiam-se, a pouco e pouco, em seções pervagantes para toda a banda; e partiam-se, estas, por seu turno, em grupos aturdidos cada vez mais dispersos e rarefeitos, dissolvendo-se ao cabo em combatentes isolados...

De longe se tinha o espetáculo estranho de um entocamento de batalhões, afundando, de súbito, no casario indistinto, em cujos tetos de argila se enovelava a fumarada dos primeiros incêndios.

Deste modo, o ataque assumiu logo o caráter menos militar possível. Diferenciou-se em conflitos parciais no cunhal das esquinas, à entrada e dentro das casas.

Estas eram tumultuariamente investidas. Não opunham o menor tropeço. Escancarava-as um coice de arma nas portas ou nas paredes, rachando-as, abrindo por qualquer lado passagens francas. Estavam vazias muitas. Noutras os intrusos tinham, de repente, abocado ao peito um cano de espingarda, ou baqueavam batidos de tiros à queima-roupa, rompendo dos resquícios das paredes. Acudiam-nos os companheiros mais próximos. Enredava-se o pugilato corpo a corpo, brutalmente, até que os soldados, mais numerosos, transpusessem o portal estreito do casebre. Lá dentro, encouchado num recanto escuro, o morador repelido descarregava-lhes em cima o último tiro e fugia. Ou então esperava-os a pé firme, defendendo tenazmente o lar paupérrimo. E revidava terrivelmente — sozinho — em porfia com a matula vitoriosa, com a qual se afoitava, apelando para todas as armas: repelindo-a a faca e a tiro; vibrando-lhe foiçadas; aferroando-a com a aguilhada; arremessando-lhe em cima os trastes miseráveis; arrojando-se, afinal, ele próprio, inerme, desesperadamente, resfolegando, procurando estrangular o primeiro que lhe caísse entre os braços vigorosos. Em torno mulheres desatinadas disparavam em choros, e rolavam pelos cantos; até baquear no chão, cosido à baioneta ou esmoído a coronhadas, pisoado sob o rompão dos coturnos, o lutador temerário.

\section{Reproduziam-se tais cenas.}

\section{Saque antes do triunfo}

Quase sempre, depois de expugnar a casa, o soldado faminto não se forrava à ânsia de almoçar, afinal, em Canudos. Esquadrinhava os jiraus suspensos. Ali estavam carnes secas ao Sol; cuias cheias de paçoca, a farinha de guerra do sertanejo; aiós repletos de ouricuris saborosos. A um 
canto os bogós transudantes, túmidos de água cristalina e fresca. Não havia resistir. Atabalhoadamente fazia a refeição num minuto. Completava-a largo trago de água. Tinha, porém, às vezes, um pospasto crudelíssimo e amargo - uma carga de chumbo...

Os jagunços à porta assaltavam-no. E invertiam-se os papéis, revivendo o conflito, até baquear no chão - cosido à faca e moído a pauladas, pisado pela alpercata dura o lutador imprudente.

\section{No labirinto das vielas}

Muitos se perdiam no inextricável dos becos. Correndo no encalço do sertanejo em fuga, topavam, de súbito, na frente, desembocando doma esquina, cerrado magote de inimigos. Estacavam, atônitos, apenas o tempo necessário para uma pontaria mal feita e uma descarga; e recuavam, depois, metendo-se pelas casas dentro, onde os salteavam, às vezes, novos agressores entocaiados; ou arrolavam-se atrevidamente, dispersando o agrupamento antagonista e dispersando-se — reeditando os mesmos episódio; animados todos pela ilusão de uma vitória vertiginosamente alcançada, de que lhes eram sintoma claro toda aquela desordem, todo aquele espanto, todo aquele alarido e todo aquele pavor do povoado revolto e miserando - alarmado à maneira de um curral invadido por onças bravias e famulentas.

De resto, não tinham insuperáveis obstáculos enfreando-lhes o ímpeto. Os valentes temerários, que apareciam em vários pontos, defendendo os lares, tinham o contrapeso do mulherio acobardado, sacudido das casas a pranchada, a bala e a fogo, e fugindo para toda a banda, clamando, rezando; ou uma legião armada de muletas — velhos trementes, aleijões de toda espécie, enfermos abatidos e mancos.

De sorte que nestas correrias desapoderadas, presos pela vertigem perseguidora, muitos se extraviaram, às tontas, no labirinto das vielas; e, tentando aproximar-se dos companheiros, desgarravam-se mais e mais quebrando, a esmo, mil esquinas breves, perdidos por fim, no arraial convulsionado e imenso.

\section{Situação inquietadora}

À frente do seu estado-maior, na margem direita do rio, o chefe expedicionário observava este assalto, acerca do qual não podia certamente formular uma única hipótese. A tropa desaparecera toda nos mil latíbulos de Canudos. Lá dentro rolava ruidosamente a desordem, numa assonância golpeada de estampidos, de imprecações, de gritos estrídulos, vibrantes no surdo tropear das cargas. Grupos esparsos, seções em desalinho de soldados, magotes diminutos de jagunços, apareciam, por vezes, inopinadamente, no claro da praça; e desapareciam, logo, mal vistos entre o fumo, embrulhados, numa luta braço a braço...

Nada mais. A situação era afinal inquietadora.

Nada prenunciava desânimo entre os sertanejos.

Os atiradores da igreja nova permaneciam firmes, visando todos os pontos quase impunemente, porque a artilharia por fim evitava alvejá-la temendo quaisquer desvios de trajetória, que lançassem as balas entre os próprios companheiros encobertos; e, estalando em cheio no arruído da refrega, ouviam-se mais altas as pancadas repetidas do sino na igreja velha.

Além disto, a ação abrangia apenas a metade do arraial. indene.

A outra, à direita, onde terminava a estrada de Jeremoabo, estava

Menos compacta - era menos expugnável. Desenrolava-se numa lomba extensa, permitindo a defesa a cavaleiro do inimigo, e obrigando-o a escaladas penosíssimas. De sorte que, ainda quando a parte investida fosse conquistada, aquela restaria impondo talvez maiores fadigas.

Realmente, embora sem o torvelinho dos becos, as casas isoladas, em disposição recordando vagamente tabuleiros de xadrez, facultavam extraordinário cruzamento de fogos, permitindo a um atirador único apontar para os quadrantes sem abandonar uma esquina. Considerando aquele lado do arraial a situação aclarava-se. Era gravíssima. Ainda contando com o sucesso franco na parte combatida, os soldados triunfantes, mas exaustos, arremeteriam, inúteis, com aquela encosta separada da praça pelo fosso natural de uma sanga profunda. Compreendeu-o o coronel Moreira César. E 
ao chegarem a retaguarda, a polícia e o esquadrão de cavalaria, determinou que aquela seguisse à extrema direita, atacando o bairro ainda indene e completando a ação que se desdobrara toda na esquerda. A cavalaria, secundando-a, teve ordem de atacar pelo centro, entre as igrejas.

Uma carga de cavalaria em Canudos...

Era uma excentricidade. A arma clássica das planícies rasas, cuja força é o arremesso do choque, surgindo de improviso no fim das disparadas velozes, ali, constrita entre paredes, carregando, numa desfilada dentro de corredores...

O esquadrão - cavalos abombados, rengueando sobre as pernas bambas - largou em meio galope curto até à beira do rio, cujas águas respingavam chofradas de tiros; e não foi adiante. Os animais assustadiços refugavam. Dilacerados à espora, chibateados à espada, mal vadearam até o meio da corrente, e empinando, e curveteando, freios tomados nos dentes, em galões, cuspindo da sela os cavaleiros, volveram em desordem à posição primitiva. Por seu turno, a polícia, depois de transpor o rio com água pelos joelhos, numa curva a jusante, vacilava ao deparar o álveo resvaladio e fundo da sanga que naquele ponto corre de norte a sul, separando do resto do arraial o subúrbio que devia acometer.

O movimento complementar quebrava-se assim aos primeiros passos. O chefe expedicionário deixou então o lugar em que permanecera, à meia encosta dos Pelados, entre a artilharia e o plaino das quixabeiras

— Eu vou dar brio àquela gente...

\section{Moreira César fora de combate}

E descia. A meio caminho, porém, refreou o cavalo. Inclinou-se, abandonando as rédeas, sob o alção dianteiro do selim. Fora atingido no ventre por uma bala.

Rodeou-o logo o estado-maior.

- Não foi nada; um ferimento leve, disse, tranquilizando os companheiros dedicados. Estava mortalmente ferido.
Não descavalgou. Volvia amparado pelo tenente Ávila, para o lugar que deixara, quando foi novamente atingido por outro projétil. Estava fora de combate.

Devia substituí-lo o coronel Tamarindo, a quem foi logo comunicado o desastroso incidente. Mas aquele nada podia deliberar recebendo o comando quando desanimava de salvar o seu próprio batalhão, na outra margem do rio.

Era um homem simples, bom e jovial, avesso a bizarrear façanhas. Chegara aos sessenta anos candidato a uma reforma tranquila. Fora, ademais, incluído contra a vontade na empresa. E, ainda quando tivesse envergadura para aquela crise, não havia mais remediá-la.

A polícia, investindo, copiara afinal o modo de agir dos outros assaltantes — varejando casas e ateando incêndios.

Não se rastreava na desordem o mais leve traço de combinação tática; ou não se podia mesmo imaginá-la.

Aquilo não era um assalto. Era um combater temerário contra barricada monstruosa, que se tornava cada vez mais impenetrável à medida que a arruinavam e carbonizavam, porque sob os escombros, que atravancavam as ruas, sob os tetos abatidos e entre os esteios fumegantes, deslizavam melhor, a salvo, ou tinham mais invioláveis esconderijos, os sertanejos emboscados.

Além disto, despontava, inevitável, contratempo maior: a noite prestes a confundir os combatentes exaustos de cinco horas de peleja.

\section{Recuo}

Mas antes que ela sobreviesse, começou o recuo. Apareceram sobre a ribanceira esquerda, esparsos, em grupos estonteadamente correndo, os primeiros contingentes repelidos. Em breve outros se lhes aliaram no mesmo desalinho, rompendo dos cunhais das igrejas e dentre os casebres marginais: soldados e oficiais de mistura, chamuscados e poentos, fardas em tiras, correndo, disparando ao acaso as espingardas, vociferando, alarmados, tontos, titubeantes, em fuga... 
Este refluxo que começara à esquerda propagou-se logo à extrema direita. De sorte que, rebatida às posições primitivas, toda a linha do combate rolou torcida e despedaçada a tiros pela borda do rio abaixo.

Sem comando, cada um lutava a seu modo. Destacaram-se ainda diminutos grupos para queimarem as casas mais próximas ou travarem breves tiroteios. Outros, sem armas e feridos, principiaram a repassar o rio.

\section{Era o desenlace.}

Repentinamente, largando as últimas posições, os pelotões, de mistura, numa balbúrdia indefinível, sob a hipnose do pânico, enxurraram na corrente rasa das águas!

Repelindo-se; apisoando os malferidos, que tombavam; afastando rudemente os extenuados trôpegos; derrubando-os, afogando-os, os primeiros grupos bateram contra a margem direita. Aí, ansiando por vingála, agarrando-se às gramíneas escassas, especando-se nas armas, filando-se às pernas dos felizes que conseguiam vencê-las, se embaralham outra vez em congérie ruidosa. Era um fervilhar de corpos transudando vozear estrídulo, e discordante, e longo, dando a ilusão de alguma enchente repentina, em que o Vaza-Barris, engrossado, saltasse, de improviso, fora do leito, borbulhando, acachoando, estrugindo...

\section{Ao bater da Ave-Maria}

Naquele momento o sineiro da igreja velha interrompeu o alarma.

Vinha caindo a noite. Dentro da claridade morta do crepúsculo soou, harmoniosamente, a primeira nota da Ave-Maria.

Descobrindo-se, atirando aos pés os chapéus de couro ou os gorros de azulão, e murmurando a prece habitual, os jagunços dispararam a última descarga...

\section{Capítulo V}

\section{Sobre o Alto do Mário}

Os soldados, transposto o rio, acumularam-se junto à artilharia. Eram uma multidão alvorotada sem coisa alguma recordando a força militar, que se decompusera, restando, como elementos irredutíveis, homens atônitos e inúteis, e tendo agora, como preocupação exclusiva, evitarem o adversário que tão ansiosamente haviam procurado.

O cerro em que se reuniam estava próximo demais daquele, e passível, talvez, de algum assalto, à noite. Era forçoso abandoná-lo. Sem ordem, arrastando os canhões, deslocaram-se logo para o Alto do Mário, quatrocentos metros na frente. Ali improvisaram um quadrado incorreto, de fileiras desunidas e bambas, envolvendo a oficialidade, os feridos, as ambulâncias, o trem da artilharia e os cargueiros. Centralizava-o uma palhoça em ruínas - a Fazenda Velha; e dentro dela o comandante-emchefe moribundo...

A expedição era agora aquilo: um bolo de homens, animais, fardas e espingardas, entupindo uma dobra de montanha...

Tinha descido a noite - uma destas noites ardentíssimas mas vulgares no sertão, em que cada estrela, fixa, sem cintilações, irradia como um foco de calor e os horizontes, sem nuvens, iluminam-se, de minuto em minuto, como se refletissem relâmpagos de tempestades longínquas...

Não se via o arraial. Alguns braseiros sem chamas, de madeiras ardendo sob o barro das paredes e tetos; ou luzes esparsas de lanternas mortiças bruxuleando nas sombras, deslizando vagarosamente, como em pesquisas lúgubres, indicavam-no embaixo, e traindo também a vigília do inimigo. Tinham, porém, cessado os tiros e nem uma voz dali subia. Apenas na difusão luminosa das estrelas desenhavam-se, dúbios, os perfis imponentes das igrejas. Nada mais. A casaria compacta, as colinas circundantes, as montanhas remotas, desapareciam na noite.

O acampamento em desordem contrastava a placidez ambiente. Constritos entre os companheiros, cento e tantos feridos e estropiados por 
ali se agitavam ou se arrastavam, torturados de dores e da sede, quase pisados pelos cavalos que espavoridos nitriam, titubeando no atravancamento das carretas e fardos dos comboios. Não havia curá-los no escuro onde fora temeridade incrível o rápido fulgurar de um fósforo. Além disto não bastava para tantos o número reduzido de médicos, um dos quais - morto, extraviado ou preso — desaparecera à tarde para nunca mais tornar $^{1}$.

\section{O coronel Tamarindo}

Faltava, ademais, um comando firme. O novo chefe não suportava as responsabilidades que o oprimiam. Maldizia talvez, mentalmente, o destino extravagante que o tornara herdeiro forçado de uma catástrofe. Não deliberava. A um oficial, que ansiosamente o interpelara sobre aquele transe, respondera com humorismo triste, rimando um dito popular do Norte:

\section{É tempo de murici}

$$
\text { Cada um cuide de si... }
$$

Foi a sua única ordem do dia. Sentado na caixa de um tambor, chupando longo cachimbo, com o estoicismo doente do próprio desalento, o coronel Tamarindo, respondendo de tal jeito, ou por monossílabos, a todas as consultas, abdicara a missão de remodelar a turba esmorecida e ao milagre de subdividi-la em novas unidades de combate.

Ali estavam, certo, homens de valor e uma oficialidade pronta ao sacrifício. O velho comandante, porém, tivera a intuição de que um ajuntamento em tais conjunturas não significa a soma das energias isoladas e avaliara todos os elementos que, nas coletividades presas de emoções violentas, reduzem sempre as qualidades pessoais mais brilhantes. Quedava impassível, alheio à ansiedade geral, passando de modo tácito o comando a toda a gente. Assim, oficiais incansáveis davam por conta própria providências mais urgentes; retificando o pretenso quadrado, em que se misturavam, a esmo, praças de todos os corpos; organizando ambulâncias e dispondo padiolas; reanimando os ânimos; abatidos. Pelo espírito de muitos passara mesmo o intento animador de um revide, um novo assalto logo ao

${ }^{1}$ Dr. Fortunato Raimundo de Oliveira. despontar da manhã, descendo a força toda, em arremetida violenta, sobre os fanáticos, depois que os abalasse um bombardeio maior do que o realizado. E concertavam-se em planos visando corrigir o revés com um lance de ousadia. Porque a vitória devia ser alcançada a despeito dos maiores sacrifícios. Pensavam: nos quatro lados daquele quadrado mal feito inscreviam-se os destinos de República. Era preciso vencer. Repugnava-os, revoltava-os, humilhava-os angustiosamente aquela situação ridícula e grave, ali, no meio de canhões modernos, sopesando armas primorosas, sentados sobre cunhetes repletos de cartuchos - e encurralados por uma turba de matutos turbulentos..

A maioria, porém, considerava friamente as coisas. Não se iludia. Um rápido confronto entre a tropa que chegara horas antes, entusiasta e confiante na vitória e a que ali estava, vencida, patenteava-lhe uma solução única - a retirada.

\section{Alvitre de retirada}

Não havia alvitrar outro recurso, ou protraí-lo sequer.

Às onze horas, juntos os oficiais, adotaram-no, unânimes. Um capitão de infantaria foi incumbido de cientificar da resolução o coronel Moreira César. Este impugnou-a logo, dolorosamente surpreendido; a princípio calmo, apresentando os motivos inflexíveis do dever militar e demonstrando que ainda havia elementos para uma tentativa qualquer, mais de dois terços da tropa apta para o combate e munições suficientes; depois, num crescendo de cólera e de angústia, se referiu à mácula que para sempre lhe sombrearia o nome. Finalmente explodiu: não o sacrificassem àquela covardia imensa...

Apesar disto manteve-se a resolução.

\section{Protesto de Moreira César}

Era completar a agonia do valente infeliz. Revoltado, deu a sua última ordem: fizessem uma ata de tudo aquilo, deixando-lhe margem para um protesto, em que incluiria o abandono da carreira militar.

A dolorosa reprimenda do chefe ferido por duas balas não moveu, contudo, a oficialidade incólume. 
Rodeavam-na, perfeitamente válidos ainda, centenares de soldados, oitocentos talvez; dispunha de dois terços das munições e estava em posição dominante sobre o inimigo...

Mas a luta sertaneja começara, naquela noite, a tomar a feição misteriosa que conservaria até o fim. Na maioria mestiços, feitos da mesma massa dos matutos que os soldados, abatidos pelo contragolpe de inexplicável revés, em que baqueara o chefe reputado invencível, ficaram sob a sugestão empolgante do maravilhoso, invadidos de terror sobrenatural, que extravagantes comentários agravavam.

O jagunço, brutal e entroncado, diluía-se em duende intangível. Em geral os combatentes, alguns feridos mesmo no recente ataque, não haviam conseguido ver um único; outros, os da expedição anterior, acreditavam, atônitos e absortos ante o milagre estupendo, ter visto, ressurretos, dois ou três cabecilhas que, afirmavam convictos, tinham sido mortos no Cambaio; e para todos, para os mais incrédulos mesmo, começou a despontar algo de anormal nos lutadores-fantasmas, quase invisíveis, ante os quais haviam embatido impotentes, mal os lobrigando, esparsos e diminutos, rompendo temerosos dentre ruínas, e atravessando incólumes os braseiros dos casebres em chamas.

É que grande parte dos soldados era do Norte, e criara-se ouvindo, em torno, de envolta com o dos heróis dos contos infantis, o nome de Antônio Conselheiro. E a sua lenda extravagante, os seus milagres, as suas façanhas de feiticeiro sem par, apareciam-lhes - então — verossímeis, esmagadoramente, na contraprova tremenda daquela catástrofe.

Pelo meio da noite todas apreensões se avolumaram. As sentinelas cabeceavam nas fileiras frouxas do quadrado, estremeceram, subitamente despertas, contendo gritos de alarma.

Um rumor indefinível avassalara a mudez ambiente e subia pelas encostas. Não era, porém, um surdo tropear de assalto. Era pior. O inimigo, embaixo, no arraial invisível — rezava.

E aquela placabilidade extraordinária - ladainhas tristes, em que predominavam, ao invés de brados varonis, vozes de mulheres, surgindo da ruinaria de um campo de combate - era, naquela hora, formidável. Atuava pelo contraste. Pelo burburinho da soldadesca pasma, os kyries estropiados e dolentes entravam, piores que intimações enérgicas. Diziam, de maneira eloquente, que não havia reagir contra adversários por tal forma transfigurados pela fé religiosa.

A retirada impunha-se.

Pela madrugada uma nova emocionante tornou-a urgentíssima. Falecera o coronel Moreira César.

\section{Retirada}

Era o último empuxo no desânimo geral. Os aprestos da partida fizeram-se, então, no atropelo de um tumulto indescritível. De sorte que, quando ao primeiro bruxulear da manhã uma força constituída por praças de todos corpos abalou, fazendo a vanguarda, encalçada pelas ambulâncias, cargueiros, fardos, feridos e padiolas, entre as quais a que levantava o corpo do comandante malogrado, nada indicava naquele momento a séria operação de guerra que ia realizar-se.

A retirada era a fuga. Avançando pelo espigão do morro no rumo da Favela e dali derivando pelas vertentes opostas, por onde descia a estrada, a expedição espalhava-se longamente pelas encostas, dispersando-se sem ordem, sem formaturas.

Neste dar as costas ao adversário que, desperto, embaixo, não a perturbara ainda, parecia confiar apenas na celeridade do recuo, para se libertar. Não se dividira em escalões, dispondo-se à defesa-ofensiva característica desses momentos críticos da guerra. Precipitava-se, à toa, pelos caminhos fora. Não retirava, fugia. Apenas uma divisão de dois Krupps, sob o mando de um subalterno de valor, e fortalecida por um contingente de infantaria, permanecera firme por algum tempo no Alto do Mário, como uma barreira anteposta à perseguição inevitável.

\section{Vaia}

Ao mover-se, afinal, esta fração abnegada foi rudemente investida. O inimigo tinha na ocasião o alento do ataque e a certeza na própria temibilidade. Acometeu ruidosamente, entre vivas entusiásticos, por todos os lados, em arremetida envolvente. Embaixo começou a bater desabaladamente o sino; a igreja nova explodia em descargas, e, adensada 
no largo, ou correndo para o alto das colinas, toda a população de Canudos contemplava aquela cena, dando ao trágico do lance a nota galhofeira e irritante de milhares de assovios estridentes, longos, implacáveis...

Mais uma vez o drama temeroso da guerra sertaneja tinha o desenlace de uma pateada lúgubre.

O desfecho foi rápido. A última divisão de artilharia replicou por momentos e depois, por sua vez, abalou vagarosamente, pelo declive do espigão acima, retirando.

Era tarde. Adiante até onde alcançava o olhar, a expedição, esparsa e estendida pelos caminhos, estava, de ponta a ponta, flanqueada pelos jagunços...

\section{Capítulo VI}

\section{Debandada. Fuga}

E foi uma debandada.

Oitocentos homens desapareciam em fuga, abandonando as espingardas; arriando as padiolas, em que se estorciam feridos: jogando fora as peças de equipamento; desarmando-se; desapertando os cinturões, para a carreira desafogada; e correndo, correndo ao acaso, correndo em grupos, em bandos erradios, correndo pelas estradas e pelas trilhas que as recortam, correndo para o recesso das caatingas, tontos, apavorados, sem chefes...

Entre os fardos atirados à beira do caminho ficara, logo ao desencadear-se o pânico — tristíssimo pormenor! — o cadáver do comandante. Não o defenderam. Não houve um breve simulacro de repulsa contra os inimigos, que não viam e adivinhavam no estrídulo dos gritos desafiadores e nos estampidos de um tiroteio irregular e escasso, como o de uma caçada. Aos primeiros tiros os batalhões diluíram-se.

\section{Salomão da Rocha}

Apenas a artilharia, na extrema retaguarda, seguia vagarosa e unida, solene quase, na marcha habitual de uma revista, em que parava de quando em quando para varrer a disparos as margens traiçoeiras; e prosseguindo depois, lentamente, rodando, inabordável, terrível...

A dissolução da tropa parara no aço daqueles canhões cuja guarnição diminuta se destacava maravilhosamente impávida, galvanizada pela força moral de um valente.

De sorte que no fim de algum tempo em torno dela se adensaram, mais numerosos, os perseguidores.

O resto da expedição podia escapar-se a salvo. Aquela bateria libertava-a. De encontro aos quatro Krupps de Salomão da Rocha, como de encontro a uma represa, embatia, e parava, adunava-se, avolumando, e recuava, e partia-se a onda rugidora dos jagunços. 
Naquela corrimaça sinistra em que a ferocidade e a covardia revoluteavam confundidas sob o mesmo aspecto revoltante, abriu-se de improviso um episódio épico.

Contidos a princípio em distância, os sertanejos constringiam a pouco e pouco o círculo do ataque, em roda das duas divisões, que os afrontavam, seguindo a passo tardo, ou, de súbito, alinhando-se em batalha e arrebentando em descargas, fulminando-os...

As granadas explodindo entre os restolhos secos do matagal incendiavam-nos; ouviam-se lá dentro, de envolta com o crepitar de queimadas sem labaredas, extintas nos brilhos da manhã claríssima, brados de cólera e de dor; e tontos de fumo, saltando dos esconderijos em chamas, rompentes à ourela da caatinga junto à estrada, os sertanejos em chusma, gritando, correndo, disparando os trabucos e as pistolas — assombrados ante aquela resistência inexplicável, vacilantes no assaltar a zargunchadas e à faca o pequeno grupo de valentes indomáveis.

Estes, entretanto, mal podiam prosseguir. Reduziam-se. Um a um tombavam os soldados da guarnição estoica. Feridos ou espantados, os muares da tração empacavam; torciam de rumo; impossibilitavam a marcha.

A bateria afinal parou. Os canhões, emperrados, imobilizaram-se numa volta do caminho...

O coronel Tamarindo, que volvera à retaguarda, agitando-se destemeroso e infatigável entre os fugitivos, penitenciando-se heroicamente, na hora da catástrofe, da tibieza anterior, ao deparar com aquele quadro estupendo, procurou debalde socorrer os únicos soldados que tinham ido a Canudos. Neste pressuposto ordenou toques repetidos de “meia volta, alto!". As notas das cornetas, convulsivas, emitidas pelos corneteiros sem fôlego, vibraram inutilmente. Ou melhor - aceleraram a fuga. Naquela desordem só havia uma determinação possível: “debandar!”.

Debalde alguns oficiais, indignados, engatilhavam revólveres ao peito dos foragidos. Não havia contê-los. Passavam; corriam; corriam doidamente; corriam dos oficiais; corriam dos jagunços; e ao verem aqueles, que eram de preferência alvejados pelos últimos, caírem malferidos, não se comoviam. O capitão Vilarim batera-se valentemente quase só, e ao baquear, morto, não encontrou entre os que comandava um braço que o sustivesse. Os próprios feridos e enfermos estropiados lá se iam, cambeteando, arrastando-se penosamente, imprecando os companheiros mais ágeis...

As notas das cornetas vibravam em cima desse tumulto, imperceptíveis, inúteis...

Por fim cessaram. Não tinham a quem chamar. A infantaria desaparecera...

Pela beira da estrada, viam-se apenas peças esparsas de equipamento, mochilas e espingardas, cinturões e sabres, jogados a esmo por ali fora, como coisas imprestáveis.

Inteiramente só, sem uma única ordenança, o coronel Tamarindo lançou-se desesperadamente, o cavalo a galope, pela estrada - agora deserta - como se procurasse conter ainda, pessoalmente, a vanguarda. E a artilharia ficou afinal inteiramente em abandono, antes de chegar ao Angico.

Os jagunços lançaram-se então sobre ela.

Era o desfecho. O capitão Salomão tinha apenas em torno meia dúzia de combatentes leais. Convergiram-lhe em cima os golpes; e ele tombou, retalhado a foiçadas, junto dos canhões que não abandonara.

Consumara-se a catástrofe...

Logo adiante, na ocasião em que transpunha a galope o córrego do Angico, o coronel Tamarindo foi precipitado do cavalo por uma bala. O engenheiro militar Alfredo do Nascimento alcançou-o ainda com vida. Caído sobre a ribanceira, o velho comandante murmurou ao companheiro que o procurara a sua última ordem:

\section{- Procure o Cunha Matos...}

Esta ordem dificilmente podia ser cumprida.

\section{Um arsenal ao ar livre}

A terceira expedição anulada, dispersa, desaparecera. E como na maioria os fugitivos evitassem a estrada, desgarraram sem rumo, errando à toa no deserto, onde muitos, entre eles os feridos, se perderam para sempre, 
agonizando e morrendo no absoluto abandono. Alguns, desviando-se da rota, foram bater no Cumbe ou em pontos mais remotos. O resto chegou no outro dia a Monte Santo. O coronel Sousa Meneses, comandante da praça, não os esperou. Ao saber do desastre largou à espora feita para Queimadas, até onde se prolongara aquela disparada.

Enquanto isto sucedia, os sertanejos recolhiam os despojos. Pela estrada e pelos lugares próximos jaziam esparsas armas e munições, de envolta com as próprias peças do fardamento, dólmãs e calças de listra carmesim, cujos vivos denunciadores demais no pardo da caatinga os tornavam incompatíveis com a fuga. De sorte que a maior parte da tropa não se desarmara apenas diante do adversário. Despira-se...

Assim na distância que medeia do Rosário a Canudos, havia um arsenal desarrumado, ao ar livre, e os jagunços tinham com que se abastecerem a fartar. A expedição Moreira César parecia ter tido um objetivo único: entregar-lhes tudo aquilo, dar-lhes de graça todo aquele armamento moderno e municiá-los largamente.

\section{Uma diversão cruel}

Levaram para o arraial os quatro Krupps; substituíram nas mãos dos lutadores da primeira linha as espingardas velhas de carregamento moroso pelas Mannlichers e Comblains fulminantes; e como as fardas, cinturões e bonés, tudo quanto havia tocado o corpo maldito das praças, lhes maculariam a epiderme de combatentes sagrados, aproveitaram-nos de um modo cruelmente lúgubre.

Os sucessos anteriores haviam-lhes exacerbado a um tempo o misticismo e a rudeza. Partira-se o prestígio do soldado, e a bazófia dos broncos cabecilhas repastava-se das mínimas peripécias dos acontecimentos. A força do governo era agora realmente a fraqueza do governo, denominação irônica destinada a permanecer por todo o curso da campanha. Haviam-na visto chegar - imponente e terrível — apercebida de armas ante as quais eram brincos de criança os clavinotes brutos; tinham-na visto rolar terrivelmente sobre o arraial, e assaltá-lo, e invadi-lo, e queimá-lo, varando-o de ponta a ponta; e, depois destes arrancos temerários, presenciaram o recuo, e a fuga, e a disparada doida, e o abandono pelos caminhos fora das armas e bagagens.
Era sem dúvida um milagre. O complexo dos acontecimentos perturbava-os e tinha uma interpretação única: amparava-os visivelmente a potência superior da divindade.

E a crença, revigorada na brutalidade dos combates, crescendo, maior, num reviver de todos os instintos bárbaros, malignou-lhes a índole.

Atesta-o fato estranho, espécie de divertimento sinistro, lembrando a religiosidade trágica dos Achantis, que rematou estes sucessos.

Concluídas as pesquisas nos arredores, e recolhidas as armas e munições de guerra, os jagunços reuniram os cadáveres que jaziam esparsos em vários pontos. Decapitaram-nos. Queimaram os corpos. Alinharam depois, nas duas bordas da estrada, as cabeças, regularmente espaçadas, fronteando-se, faces volvidas para o caminho. Por cima, nos arbustos marginais mais altos, dependuraram os restos de fardas, calças e dólmãs multicores, selins, cinturões, quepes de listras rubras, capotes, mantas, cantis e mochilas...

A catinga, mirrada e nua, apareceu repentinamente desabrochando numa florescência extravagantemente colorida no vermelho forte das divisas, no azul desmaiado dos dólmãs e nos brilhos vivos das chapas dos talins e estribos oscilantes...

Um pormenor doloroso completou esta encenação cruel: a uma banda avultava, empalado, erguido num galho seco, de angico, o corpo do coronel Tamarindo.

Era assombroso.. . Como um manequim terrivelmente lúgubre, o cadáver desaprumado, braços e pernas pendidos, oscilando à feição do vento no galho flexível e vergado, aparecia nos ermos feito uma visão demoníaca.

\section{Ali permaneceu longo tempo...}

Quando, três meses mais tarde, novos expedicionários seguiam para Canudos, depararam ainda o mesmo cenário: renques de caveiras branqueando as orlas do caminho, rodeadas de velhos trapos, esgarçados nos ramos dos arbustos e, de uma banda, - mudo protagonista de um drama formidável, - o espectro do velho comandante... 